
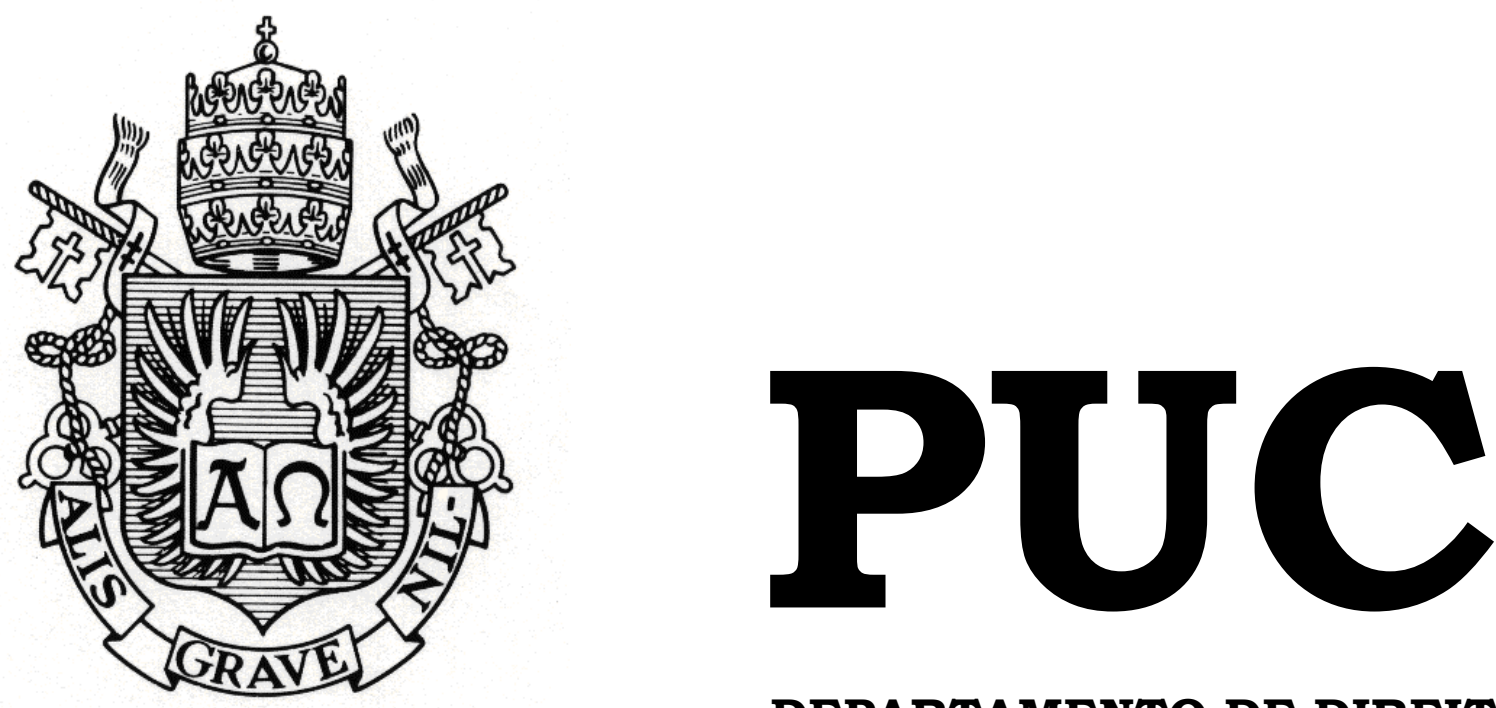

DEPARTAMENTO DE DIREITO

\title{
MÚTUO DE AÇÕES: UMA ANÁLISE DAS PRINCIPAIS REPERCUSSÕES JURÍDICAS
}

por

MARÍLIA CARNEIRO DA CUNHA LOPES

ORIENTADOR: MARCELO FERNANDEZ

TRINDADE

2014.1

PONTIFÍCIA UNIVERSIDADE CATÓLICA DO RIO DE JANEIRO

RUA MARQUÊS DE SÃO VICENTE, 225 - CEP 22453-900

RIO DE JANEIRO - BRASIL 


\section{MÚTUO DE AÇÕES: UMA ANÁLISE DAS PRINCIPAIS REPERCUSSÕES JURÍDICAS}

por

MARÍLIA CARNEIRO DA CUNHA LOPES

Monografia apresentada ao Departamento de Direito da Pontifícia Universidade Católica do Rio de Janeiro (PUC-Rio) para a obtenção do Título de Bacharel em Direito.

Orientador: Marcelo Fernandez Trindade 
À minha avó Violeta, de quem tanto sinto falta. 


\section{Agradecimentos}

Aos meus pais, Levy e Flávia, meus maiores exemplos, por toda dedicação e carinho com que conduziram a minha criação.

À minha avó Violeta que, infelizmente, não está mais aqui para comemorar comigo esta nova etapa, por toda doçura e amor.

Ao meu padrasto, Henrique, por ser sempre tão atencioso e paciente.

Ao meu orientador, chefe e professor que eu tanto admiro, Marcelo Trindade, não apenas pela essencial orientação neste trabalho, como também por ter despertado a minha curiosidade pelo Direito logo no primeiro ano de faculdade.

Às colegas de trabalho e queridas amigas Fernanda Bokel, Maria Antonia Barretto e Fabiana Almeida, por todo o companheirismo e cumplicidade.

Aos demais membros da Trindade Sociedade de Advogados, por todas as oportunidades e lições diárias que contribuíram de forma fundamental para a minha formação profissional.

Às grandes amizades que a PUC me trouxe, Isabel Braga, Lis Aguileira, Luísa Santos, Rafaela Muller, Camila Lobo, Luciana Caminha e Jessica Kimelblat, sem as quais esses 5 anos não teriam sido os mesmos.

Aos meus amigos Gabriel Carvalho, João Paulo Georgief e Pedro Brigagão, pelos sempre tão interessantes debates e opiniões.

E, por fim, às minhas grandes descobertas, Natália Araújo, Nathalia Prates e Stephanie Bottino, por todo apoio e amizade.

Muito obrigada! 


\section{Resumo}

LOPES, Marília Carneiro da Cunha. Mútuo de Ações: Uma Análise das Principais Repercussões Jurídicas. 95 p. Monografia (Graduação em Direito) - Pontifícia Universidade Católica do Rio de Janeiro: Rio de Janeiro, 2014.

O presente trabalho tem por objetivo analisar o conceito, a estrutura e as particularidades da operação equivocadamente denominada no mercado de "aluguel de ações", bem como definir sua natureza jurídica, examinando os efeitos daí decorrentes. Este estudo pretende, também, investigar as repercussões jurídicas que a operação pode gerar nos principais direitos políticos e patrimoniais dos acionistas, além de verificar a possibilidade de sua realização nos períodos de vedação de negociar impostos por norma regulamentar.

\section{Palavras-chave}

Direito Societário - Mercado de Capitais - BTC - Aluguel de Ações - Mútuo de Ações - Empréstimo de Ações - Direito de Participação nos Lucros Dividendos - Direito de Preferência - Direito de Retirada - Direito de Voto - Voto Abusivo - Empty Voting - Insider Trading - Vedação de Negociar Política de Negociação. 


\section{Sumário}

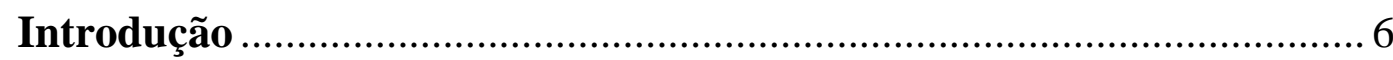

Capítulo I - O Mútuo de Ações ................................................................ 10

1.1. Conceito e Estrutura da Operação...................................................... 10

1.2. A Questão da Fungibilidade das Ações ........................................... 13

1.3. Caracteres Jurídicos do Contrato de Mútuo..................................... 18

1.4. O Equívoco da Nomenclatura e a Confusão dos Institutos ............ 21

1.5. Tipos de Contrato e Liquidação das Operações................................ 24

Capítulo II - Principais Direitos Políticos e Patrimoniais dos Acionistas 27

2.1. Direito de Participar dos Lucros .................................................. 28

2.2. Direito de Preferência Para Subscrição de Ações............................ 31

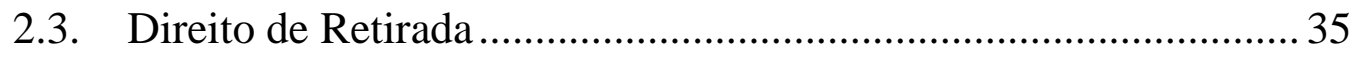

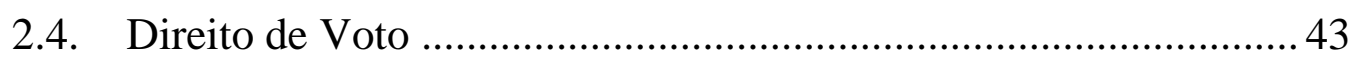

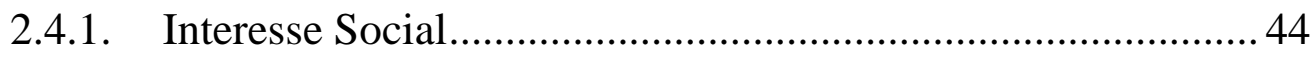

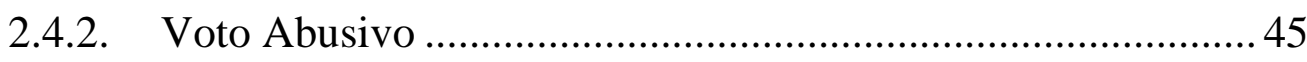

Capítulo III - Principais Direitos Políticos e Patrimoniais dos Acionistas

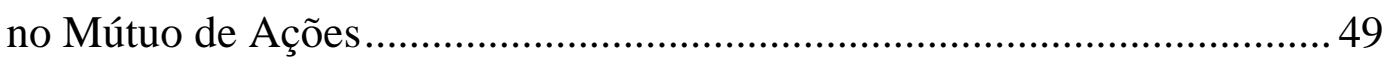

3.1. Direito de Participar nos Lucros ....................................................... 49

3.2. Direito de Preferência na Subscrição de Ações ................................ 50

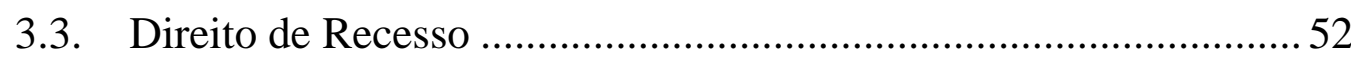

3.3.1. Necessidade de Titularidade Ininterrupta ................................52

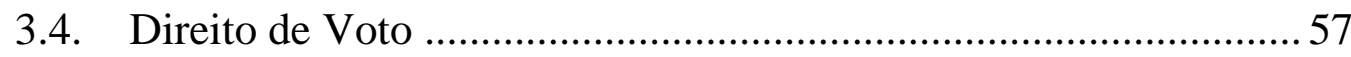

Capítulo IV - Períodos de Vedação à Negociação e o Mútuo de Ações .. 66

4.1. A Proibição da Prática de Insider Trading ......................................... 66

4.2. A Instrução CVM n ${ }^{\circ} 358$ e a Presunção Relativa ............................. 69

4.3. Mútuo de Ações e a Vedação de Negociar ....................................... 72

4.3.1. A Situação do Mutuante........................................................... 73

4.3.2. A Situação do Mutuário .......................................................... 76

4.3.3. A Implementação de Políticas de Negociação ........................... 77

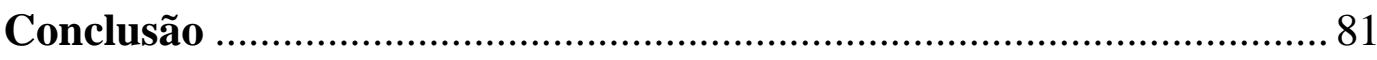

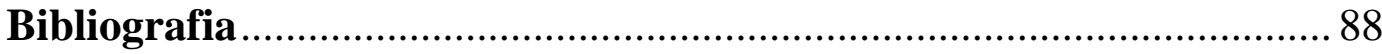




\section{Introdução}

O mútuo de ações, impropriamente conhecido no mercado de valores mobiliários como "aluguel de ações", tem ganhado crescente relevância no mercado de capitais brasileiro e mundial.

Tais operações surgiram no mercado brasileiro por volta dos anos 1970 no âmbito do mercado organizado. Na década seguinte, surgiram as primeiras regulamentações a respeito da matéria, de forma ainda muito rudimentar.

Com o decorrer dos anos, diversos organismos internacionais passaram a incentivar o desenvolvimento da prática de empréstimo de ações, com o objetivo de diminuir o risco de liquidação das operações no mercado de capitais.

Nesse sentido, confira-se a recomendação do Grupo dos Trinta ${ }^{1}$ : "as autoridades competentes devem permitir que títulos sejam tomados e doados em empréstimo como forma de maximizar a liquidação das transações com valores mobiliários"2.

Isso porque o tomador dos ativos poderá tomar ações em empréstimo para cumprir com obrigações de entregar ativos que ainda não possui. No jargão de mercado, irá “alugar” ações para cobrir posições short.

Assim, como forma de atender às crescentes necessidades do mercado, bem como às recomendações internacionais, o mútuo de ações foi regulamentado, em 1996, pela Resolução do Conselho Monetário Nacional (“CMN") $n^{\circ} 2.268$ e pela Instrução no 249 da Comissão de Valores

\footnotetext{
${ }^{1}$ Grupo internacional composto por representantes de alto escalão das principais instituições financeiras, bolsas de valores e da academia. Destina-se a aprofundar a compreensão das questões econômicas e financeiras internacionais, para explorar as repercussões internacionais das decisões tomadas nos setores público e privado, e examinar as opções disponíveis para os operadores do mercado e formuladores de políticas. http://www.group30.org/about.shtml. Acesso em 05 mar. 2014.

2 BM\&FBOVESPA, Folheto BTC, mar 2010, p. 3. http://www.bmfbovespa.com.br/ptbr/Servicos/download/Folheto-BTC.pdf. Acesso em 10 fev. 2014.
} 
Mobiliários ("CVM"). Foi criado, com isso, um serviço de empréstimo de títulos, o Banco de Títulos da atual BM\&FBOVESPA (“BTC").

Atualmente, o mercado de mútuo de ações é regulamentado pela Instrução CVM no 441, de 10 de novembro de 2006 ("Instrução CVM no 441") e pela Resolução CMN no 3.539, de 28 de fevereiro de 2008.

Além de contribuir para a redução do risco de liquidação das operações cursadas em bolsa, um mercado ativo de empréstimo de ações também tende a aumentar a liquidez dos títulos (visto que, em regra, os mutuários destinam tais ações à negociação) ${ }^{3}$, bem como possibilita a realização de operações de arbitragem, de vendas "a descoberto", a constituição de $h e d g e^{4}$, a cobertura no lançamento de opções de compra e a precificação eficiente das ações ao possibilitar a implementação de estratégias long/short ${ }^{5}$. Ademais, por estabelecer uma remuneração ao agente que realiza o empréstimo, acaba por incentivar o investimento a longo prazo no mercado de capitais.

São, portanto, inegáveis as vantagens decorrentes de um mercado desenvolvido de empréstimo de ações.

De acordo com as estatísticas divulgadas pela BM\&FBOVESPA, em seu sítio na rede mundial de computadores tais operações experimentaram um crescimento destacado no Brasil a partir do ano de 2006:

\footnotetext{
3 "Securities lending therefore provides 'liquidity". RAAIJMAKERS, Geert T. M. J. Securities Lending and Corporate Governance. Maastricht University Faculty of Law, Forthcoming, 2007, p. 3. Disponível em <http://papers.ssrn.com/sol3/papers.cfm?abstract_id=928312〉. Acesso em $10 / 04 / 2014$.

${ }^{4}$ LEUTEWILER, Gabriel; COMIRAN, Giovana Cunha; HAENSEL, Taimi. Aluguel de Ações: Panorama do negócio jurídico, problemas do direito estrangeiro e a eficiência do modelo brasileiro e a questão do voto no direito brasileiro. In: Revista de Direito Mercantil, Industrial, Econômico e Financeiro. São Paulo: Malheiros, n. 161/162, p. 173, jan/ago, 2012.

${ }^{5}$ RAAIJMAKERS, Geert T. M. J. Securities Lending and Corporate Governance. Maastricht University Faculty of Law, Forthcoming, 2007, p. 4. Disponível em $\langle$ http://papers.ssrn.com/sol3/papers.cfm?abstract_id=928312 >. Acesso em 10/04/2014.
} 


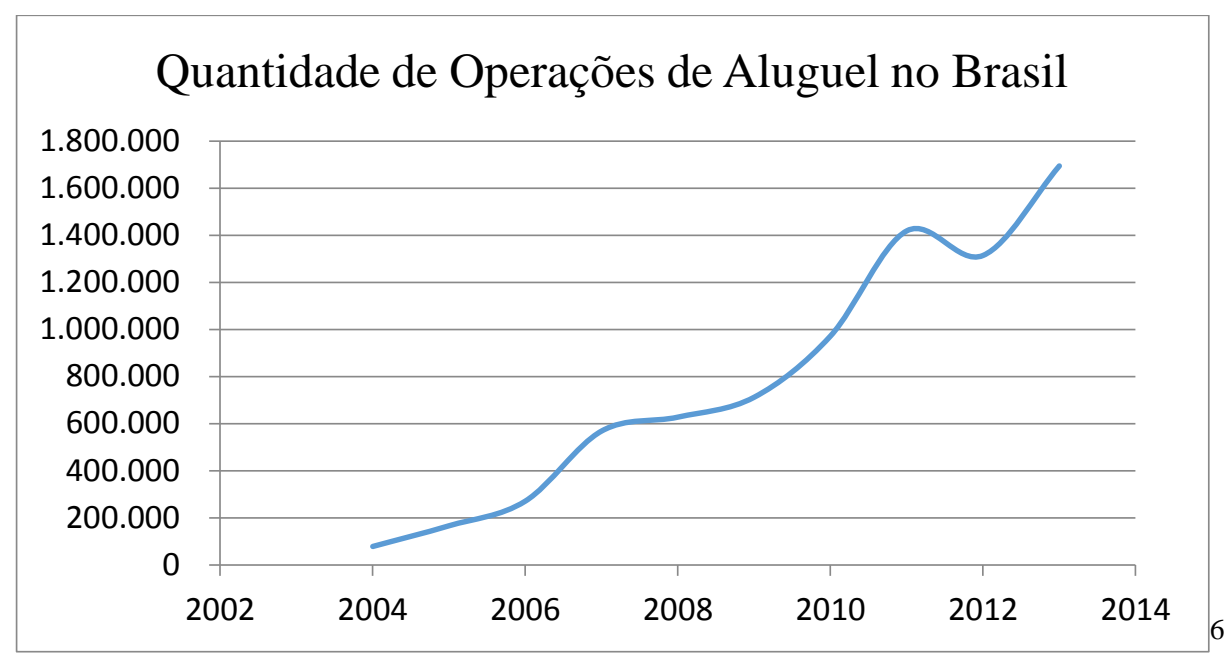

Apesar do crescimento do número de operações e da importância econômica que têm no mercado, há diversos aspectos jurídicos a elas referentes - alguns, inclusive, bastante controvertidos - que ainda não foram objeto de aprofundado estudo.

O presente trabalho visa a abordar alguns desses aspectos, sem a ousada pretensão de esgotar o tema. Como a análise limitar-se-á às operações cursadas em bolsa, este estudo tratará apenas de companhias abertas e ações negociadas no mercado bursátil.

Serão analisados, primeiramente, o conceito e a estrutura da operação, bem como as particularidades inerentes a tal negócio jurídico. A partir daí, será definida a natureza jurídica da operação e examinados os efeitos dela decorrentes, de modo a evidenciar o equívoco na nomenclatura utilizada pelo mercado.

Por sua vez, no Capítulo II, serão delineados os principais contornos a respeito dos direitos políticos e patrimoniais dos acionistas, mais especificamente, do direito de participar dos lucros, direito de preferência para subscrição de ações, direito de retirar-se da sociedade e direito de voto, para que, no Capítulo III, seja analisado como tais direitos são exercidos na

\footnotetext{
${ }^{6}$ Gráfico elaborado a partir dos dados disponíveis em <http://www.bmfbovespa.com.br/BancoTitulosBTC/Estatisticas.aspx?Idioma=pt-br>. Acesso em 25 mar. 2014.
} 
vigência do contrato de mútuo de ações, assim como suas principais repercussões jurídicas.

No Capítulo IV, será feita uma breve exposição sobre a prática de insider trading, bem como sobre as normas regulamentares que vedam a negociação de valores mobiliários em períodos restritos. Em seguida, será examinada a possibilidade de realização de operações de mútuo de ações durante esses períodos.

Por fim, a conclusão terá por objetivo abordar, de uma maneira geral, o que foi exposto ao longo deste trabalho. 


\section{Capítulo I \\ O Mútuo de Ações}

\subsection{Conceito e Estrutura da Operação}

O mútuo de ações consiste em uma operação em que o mutuante (denominado comumente de "doador") transfere ao mutuário (o "tomador") a propriedade de suas ações, mediante o recebimento de uma remuneração previamente acordada pelas partes, e este, por sua vez, tem a obrigação de entregar ações equivalentes ao final do contrato.

Desejando emprestar suas ações, o mutuante recorre a uma corretora ou distribuidora de títulos e valores mobiliários (denominados "agentes de custódia", pela BM\&FBOVESPA) e firma um termo de autorização no qual expressamente autoriza tais intermediários a realizarem operações de empréstimo com seus títulos e a transferirem-nos para uma conta de custódia ou empréstimo mantida na central depositária da Câmara de Ações (antiga CBLC), câmara de liquidação ligada à BM\&FBOVESPA.

Tais operações são, em regra, realizadas em bolsa, por meio do sistema BTC, o qual é administrado pela Câmara de Ações, havendo, portanto, uma centralização do mercado de empréstimo no Brasil. Assim, uma vez transferidos os ativos de titularidade do mutuante a uma conta de custódia ou empréstimo, deverá o agente de custódia registrar a oferta do doador por meio do sistema BTC, indicando as principais características do empréstimo (tais como espécie, classe e quantidade de ações, taxa de remuneração - negociada bilateralmente pelas partes, ainda que por adesão -, prazo de vigência do contrato, etc.).

Por outro lado, o tomador "deverá, por meio de contrato com seu intermediário, autorizá-lo a tomar ações emprestadas em seu nome, podendo este registrar ofertas na CBLC [atual Câmara de Ações] e receber as ações 
para entregá-las ao doador"7. As partes são mantidas anônimas, sem que se estabeleça qualquer vínculo entre elas.

Como contraparte central das operações, a BM\&FBOVESPA só autorizará a realização das operações de empréstimo de ações caso o tomador ofereça, em caução, ativos aceitos por ela, em valor suficiente para assegurar a liquidação de suas operações ${ }^{8}$. A suficiência de tais garantias é verificada diariamente pela Câmara de Ações, tendo em vista a importância que possui para a segurança das operações.

\section{Nesse sentido, FERNANDA KEHDI SCHAHIN:}

"A obrigatoriedade da constituição de garantias no momento de contratar uma operação de empréstimo reveste tais operações de maior segurança, além de contribuir para a credibilidade do mercado de valores mobiliários como um todo. Ao exigir o aporte de garantias, a CBLC [atual Câmara de Ações] está protegendo a parte doadora de ativos de uma situação possível de inadimplência, visto que o risco reside na ponta tomadora, ao mesmo tempo em que zela pelo bom funcionamento do sistema. A falta de salvaguardas desse tipo inviabilizaria a atividade de empréstimo de ações".

Os interesses envolvidos na operação podem resumir-se da seguinte forma: o doador de ações é geralmente investidor de médio ou longo prazo que não tem a intenção de se desfazer de forma definitiva de seus ativos, mas pretende obter alguma remuneração extra. Com isso, realizar um empréstimo de suas ações pode ser uma opção vantajosa para um investidor com esse perfil.

\footnotetext{
${ }^{7}$ KALANSKY, Daniel; PEYSER, Luis. Empréstimo de Ações e o Mercado de Capitais. In: JUNIOR, Ecio Perin; KALANSKY Daniel; PEYSER, Luis (coord.). Direito Empresarial: Aspectos atuais de Direito Empresarial brasileiro e comparado. São Paulo: Método, 2005, p. 21.

${ }^{8} \mathrm{~A}$ antiga redação da Instrução CVM no $441 / 06$ e da Regulamentação $\mathrm{CMN} \mathrm{n}{ }^{\circ} 3.278 / 05$ previa que as garantias dadas pelo tomador deveriam ser "equivalentes a $100 \%$ do valor dos valores mobiliários objeto do empréstimo, acrescido de percentual adicional destinado a compensar a variação desse valor em dois dias úteis consecutivos". A redação foi alterada com o objetivo de assegurar a certeza da liquidação das operações, em conformidade com o art. $4^{\circ}$ da Lei no 10.214, de 2001.

${ }^{9}$ SCHAHIN, Fernanda Kehdi. Vendas a Descoberto no âmbito do Empréstimo de Ações: estudo do modelo regulatório brasileiro. In: Revista de Direito Bancário e do Mercado de Capitais. São Paulo: Malheiros, n. 49, ano 13, p. 57, jul/set, 2010.
} 
Por outro lado, o tomador é, em regra, investidor de curto prazo que necessita de tais ações para garantir posições assumidas em mercados futuros ou para realizar operações com tais ações ou lastreadas em tais ações ${ }^{10}$.

Durante a vigência do contrato, poderá o mutuário usar e dispor das ações tomadas em empréstimo - como, por exemplo, aliená-las no mercado - obrigando-se a devolver ao mutuante, no vencimento do contrato, ações da mesma espécie e classe de emissão de determinada companhia. Aliás, o uso e disposição das ações está intimamente relacionado à própria finalidade do negócio de empréstimo de ações.

A estratégia do tomador está, muitas vezes, atrelada a uma expectativa de queda futura na cotação das ações que toma em empréstimo, devido à sua visão quanto a uma supervalorização daquele ativo. Assim, uma vez obtidas as ações, aliena-as a determinado preço e espera recomprá-las, no momento de devolução ao doador, a preço inferior, lucrando, dessa forma, com a diferença positiva entre o preço de venda e o preço de recompra.

Importante salientar que as ações entregues ao doador, no final do contrato, não serão exatamente aquelas que foram emprestadas ao tomador a não ser que estejamos diante de incrível coincidência -, mas outras equivalentes ${ }^{11}$.

Isso ocorre porque as ações negociadas em bolsa e, portanto, livres de quaisquer ônus que impeçam sua circulação ${ }^{12}$, são classificadas como bens

\footnotetext{
${ }^{10}$ TRINDADE, Marcelo Fernandez. Mútuo de Ações e Insider Trading. In: CASTRO, Rodrigo Rocha Monteiro de; WARDE JÚNIOR, Walfrido Jorge; GUERREIRO, Carolina Dias Tavares (Coord.). Direito Empresarial: e Outros Estudos de Direito em Homenagem ao Professor José Alexandre Tavares Guerreiro. São Paulo: Quartier Latin, 2013, p. 522.

11 "Fungíveis são os bens suscetíveis de substituição por outros da mesma espécie, qualidade e quantidade, ou, em outras palavras, determináveis por número, peso ou medida. Entre eles, a relação é de equivalência". (GOMES, Orlando. Introdução ao Direito Civil. $6^{a}$ ed. Rio de Janeiro: Forense, 1979, p. 247, destacou-se).

${ }^{12} \mathrm{O} \S 4^{\circ}$ do art. $2^{\circ}$ da Instrução CVM prevê que "somente serão admitidas operações de empréstimo que tenham por objeto valores mobiliários depositados em custódia nas entidades mencionadas no caput deste artigo, livres de ônus ou gravames que impeçam sua circulação".
} 
fungíveis, definidos no art. 85 do Código Civil como aqueles que "podem substituir-se por outros da mesma espécie, qualidade e quantidade".

Na lição de PONTES DE MIRANDA, "fungibilidade é a substituibilidade qualitativa e quantitativa", de forma que "em vez de se levar em conta a individualidade da coisa, atende-se ao gênero, que é classe" ${ }^{13}$.

O reconhecimento da fungibilidade das ações listadas em bolsa é extremamente relevante para determinar a natureza jurídica da operação ${ }^{14}$.

Note-se que apesar de a fungibilidade das ações negociadas em bolsa ser patente, uma vez que estão depositadas na instituição custodiante como valores fungíveis, não há como negar que a doutrina diverge, em parte, com relação à classificação das ações como bens fungíveis, motivo pelo qual se impõe uma análise mais aprofundada a respeito do assunto.

\subsection{A Questão da Fungibilidade das Ações}

Na lição de DANIEL KALANSKY E LUIS PEYSER,

"A preocupação em classificarmos a ação como um bem móvel fungível ou infungível dá-se em razão do fato de que, uma vez caracterizada como um bem infungivel, poderíamos chegar à conclusão de que o tomador do empréstimo não poderia dispor livremente das ações objeto de referida operação, o que retiraria do amparo legal as operações de arbitragem".

Com relação ao tratamento que a Lei no 6.404/76 ("Lei das S.A.") confere ao tema, leia-se a redação do caput art. 41:

Art. 41. A instituição autorizada pela Comissão de Valores Mobiliários a prestar serviços de custódia de ações fungíveis pode contratar custódia em que as ações de cada espécie e classe da companhia sejam recebidas em depósito como valores fungíveis, adquirindo a instituição depositária a propriedade fiduciária das ações.

Isto é, a Lei das S.A. estabelece expressamente que as instituições custodiantes manterão a propriedade fiduciária de ações fungíveis para fins de guarda, controle, administração e negociação dessas ações.

\footnotetext{
${ }^{13}$ MIRANDA, Pontes de. Tratado de Direito Privado: Parte Geral. Tomo II. $3^{\mathrm{a}}$ ed. Rio de Janeiro: Borsoi, 1970, p. 25

14 “O conceito [de fungibilidade] é assaz relevante para o conceito de mútuo". (MIRANDA, Pontes de. Tratado de Direito Privado: Parte Geral. Tomo II. $3^{\text {a }}$ ed. Rio de Janeiro: Borsoi, 1970, p. 25)
} 
O objetivo de criar-se o depósito de ações fungíveis foi justamente o de reduzir os custos de administração e facilitar a transferência dos títulos.

Nesse sentido, a exposição justificativa do projeto de lei que originou a Lei das S.A.:

"Os artigos 41 e 42, com o objetivo de reduzir os custos de administração de carteira de títulos, regulam modalidade de serviços de custódia de instituições financeiras que dispensará o registro e manipulação, em separado, dos certificados recebidos de cada depositante. Como os valores mobiliários são títulos de massa, que conferem - dentro de cada espécie e classe - iguais direitos, não há inconvenientes em que a instituição depositária devolva aos custodiantes ação igual, embora com outro número de ordem e representada por certificado diverso" $"$.

Explique-se: como a propriedade das ações nominativas stricto sensu é, em regra, presumida pela inscrição do nome do acionista no Livro de Registro de Ações Nominativas, conforme dispõe o caput do art. 31 da Lei das S.A. ${ }^{16}$, alterar os registros do livro a cada alienação ou aquisição de ações emitidas por companhia aberta com alto grau de liquidez seria praticamente inviável.

Para tanto, o sistema de depósito de ações fungíveis foi criado para facilitar tal procedimento, sendo que "esse tipo de custódia somente pode constituir-se mediante termo de transferência ou título que permita à companhia inscrever a instituição custodiária no Livro de Registro de Ações Nominativas como novo proprietário da ação"17. Dessa forma, a comprovação do titular da ação se dá mediante um extrato fornecido pela instituição custodiante.

A transferência da propriedade das ações à instituição custodiante, portanto, é precária, limitada, resolúvel, tecnicamente denominada de

15 LAMY FILHO, Alfredo; PEDREIRA, José Luiz Bulhões. A Lei das S.A.: Pressupostos, Elaboração, Aplicação. Vol I. $3^{\text {a }}$ ed. Rio de Janeiro: Renovar, 1997, p. 229.

16 Art. 31. A propriedade das ações nominativas presume-se pela inscrição do nome do acionista no livro de "Registro de Ações Nominativas" ou pelo extrato que seja fornecido pela instituição custodiante, na qualidade de proprietária fiduciária das ações.

${ }^{17}$.PEDREIRA, José Luiz Bulhões; LAMY FILHO, Alfredo. Natureza e Normas Gerais. In: LAMY FILHO, Alfredo; PEDREIRA, José Luiz Bulhões (coords.). Direito das Companhias. Vol. I. Rio de Janeiro: Forense, 2009, p. 536. 
propriedade fiduciária. Isso porque a instituição custodiante não se torna acionista da companhia, logo, não pode negociar com as ações por conta própria, tampouco exercer o direito de voto.

\section{Na lição de NELSON EIZIRIK,}

"A propriedade adquirida pela instituição depositária é limitada e resolúvel, pois (i) a transferência tem por fim apenas a guarda, o controle, a administração e a viabilização das operações com valores mobiliários depositados no âmbito dos sistemas de negociação e liquidação, ou seja, o fiduciário não pode dispor das ações; e (ii) pode ser extinta a qualquer tempo, mediante a rescisão do contrato pelo depositante, retornando a ação, ou outro valor mobiliário depositado, ao seu patrimônio. Assim, os valores mobiliários transferidos à instituição depositária, durante o prazo em que vigorar a custódia, não integram, para quaisquer fins o seu patrimônio" "18.

Já com relação às ações nominativas escriturais, a Lei das S.A. criou um sistema de registro eletrônico, sem a necessidade de emissão de certificados, em que os títulos são mantidos em contas de depósitos, em nome de seus titulares, na instituição financeira determinada pela companhia, tratando-os também como títulos fungíveis.

Segundo entende NELSON EIZIRIK, a lei denominou a custódia como de "ações fungíveis" porque "a instituição financeira depositária não é obrigada a devolver ao depositante as mesmas ações que recebeu em depósito; poderá devolver outras ações desde que sejam de emissão da mesma companhia e na mesma quantidade, espécie e classe"19.

A seu entender, a fungibilidade das ações estaria restrita apenas ao serviço de custódia, sendo "consideradas fungíveis apenas para os fins do depósito e da sua restituição ao depositante"20.

No mesmo sentido, Modesto CARVALHOSA:

"E a respeito, é conveniente lembrar que as acões nominativas registradas (art.

31) e as escriturais (art. 34) coletivamente custodiadas não perdem a sua

natureza de bens infungíveis. Temos, portanto, que as ações (...) antes de

\footnotetext{
${ }^{18}$ EIZIRIK, Nelson. A Lei das S.A. Comentada. Vol. I. São Paulo: Quartier Latin, 2011, p. 268.

${ }^{19}$ Ibid., p. 264.

${ }^{20}$ Ibid., p. 265.
} 
depositadas e após devolvidas ao acionista circulam e são negociadas sempre como coisa infungível. Apenas para efeito de depósito, e enquanto este existir, é que as características intrínsecas da infungibilidade da ação não são levadas em consideração e, portanto, suspensos os seus efeitos" $" 21$.

LuiZ Gastão PAES DE BARRos LEÃES também compartilha do mesmo entendimento:

“(..) as acões nominativas e endossáveis se revestem de natureza infungível, posto que pressupõem, a todo momento, uma clara identidade do titular no teor literal do documento, assim como no livro de registro respectivo da sociedade emitente. Todas, no entanto, podem ser consideradas fungíveis ou fungilizadas para efeito exclusivo da custódia, dado o enunciado genérico do art. 41"22.

Do mesmo modo, quando a Lei das S.A. ainda previa a existência de ações ao portador e ações endossáveis, FRAN MARTINS sustentava que o “depósito de ações como valores mobiliários fungíveis não pode abranger as ações puramente nominativas, que são individualizadas e cuja propriedade é atestada pela sua inscrição no 'Registro de Ações Nominativas $" 23$.

Ocorre que, com relação às ações nominativas stricto sensu, o número de registro das ações, por meio de sua inscrição no Livro de Registro de Ações, não retira o seu caráter fungível. Pensar o contrário seria não apenas defender um extremo formalismo, como também confundir o fato de que há um registro do proprietário com a suposta distinção entre os bens.

Isso porque desde que de mesma espécie e classe, as ações podem certamente ser substituídas entre si, pois continuam assegurando a seu titular

\footnotetext{
${ }^{21}$ CARVALHOSA, Modesto. Comentários à Lei de Sociedades Anônimas. Vol. I. $6{ }^{\mathrm{a}}$ ed. São Paulo: Saraiva, 2011, p. 490, destacou-se.

${ }^{22}$ LEÃES, Luiz Gastão Paes de Barros. Estudos e Pareceres sobre Sociedades Anônimas. São Paulo: Revista dos Tribunais, 1989, p. 42, destacou-se.

${ }^{23}$ MARTINS, Fran. Comentários à Lei das Sociedades Anônimas. $4^{\mathrm{a}}$ ed. Rio de Janeiro: Forense, 2010, p. 154.
} 
os mesmos direitos e deveres, sendo, completamente indiferente ao acionista possuir a ação de número 1 ou 2.

Na lição de FÁBIO KONDER COMPARATO,

"Dessa homogeneidade dos valores mobiliários, em cada série de emissão, decorre a característica de sua fungibilidade, ausente nos títulos de crédito. $\underline{\boldsymbol{U} \boldsymbol{m} \boldsymbol{a}}$ acão ordinária nominativa é perfeitamente substituível por outra acão ordinária nominativa, não havendo, por conseguinte, qualquer diferenca de cotacão entre valores mobiliários da mesma espécie, classe e forma, no mercado de capitais. (...) Ademais são coisas sujeitas a um mercado (graças à sua fungibilidade), isto é, mercadorias ${ }^{, 24}$.

No mesmo sentido, RUBENS REQUIÃO:

"São fungiveis, enuncia o art. 85 do Código Civil de 2002, os móveis que podem, e não-fungíveis os que não podem substituir-se por outros da mesma espécie, qualidade e quantidade. Sendo bens móveis as acões, e emitidas em massa pela sociedade anônima, tendo o mesmo valor, podem ser consideradas bens fungíveis. Claro que serão consideradas fungíveis dentro da mesma classe e sendo da mesma natureza" 25 .

Apesar de proveitoso, tal debate não apresenta muita relevância no caso do empréstimo de ações realizado em bolsa, tendo em vista que, para serem objeto de empréstimo, as ações deverão estar mantidas em custódia por instituição financeira autorizada. Sendo assim, são evidentemente bens fungíveis.

Ultrapassada a discussão acerca da fungibilidade das ações, torna-se possível caracterizar a natureza jurídica da operação de aluguel de ações como um contrato de empréstimo, mais especificamente, de um mútuo, regulado pelo art. 586 e seguintes do Código Civil, no qual são emprestados bens fungíveis - as ações - para posterior devolução de bens de mesmo

\footnotetext{
${ }^{24}$ COMPARATO, Fábio Konder. Novos Ensaios e Pareceres de Direito Empresarial. Rio de Janeiro: Forense, 1981, p. 18, destacou-se.

${ }^{25}$ REQUIÃO, Rubens. Curso de Direito Comercial. Vol. II. 24ª ed. São Paulo: Saraiva, 2005, p. 101 e 102, destacou-se.
} 
gênero, qualidade e quantidade (no caso das ações, de mesma espécie e classe). Confira-se a redação do caput do art. 586:

Art. 586. O mútuo é o empréstimo de coisas fungíveis. O mutuário é obrigado a restituir ao mutuante o que dele recebeu em coisa do mesmo gênero, qualidade e quantidade.

A fim de que não restem dúvidas quanto à natureza jurídica do "aluguel de ações", faz-se necessária uma breve análise sobre os caracteres jurídicos do contrato de mútuo.

\subsection{Caracteres Jurídicos do Contrato de Mútuo}

O contrato de mútuo, segundo a classificação de CAIO MÁRIO DA SILVA PEREIRA ${ }^{26}$, é um contrato real ${ }^{27}$, unilateral, gratuito (em regra, mas podendo ser também oneroso), temporário e translatício de domínio.

A classificação do mútuo como contrato real se dá em razão de perfazer-se com a tradição da coisa: no momento em que o mutuário passa a dispor do bem. Antes da entrega sequer é possível falar-se em contrato de mútuo, tratando-se, portanto, de elemento do contrato.

Na lição de PONTES DE MIRANDA:

\footnotetext{
${ }^{26}$ PEREIRA, Caio Mário da Silva. Instituições de Direito Civil: Contratos. Vol. III. 12a ed. Rio de Janeiro: Forense, 2006, p. 348 e 349.

${ }^{27}$ Em realidade, o próprio autor contesta tal classificação, uma vez que, a seu ver, seria razoável bastar o consenso das partes para sua celebração. Pondera, no entanto, que a sistemática elaborada pelo Código Civil de 2002 tem como requisito de constituição da relação contratual "a entrega efetiva da coisa". PEREIRA, Caio Mário da Silva. Instituições de Direito Civil: Contratos. Vol. III. $12^{\mathrm{a}}$ ed. Rio de Janeiro: Forense, 2006, p. 348. Maria Celina Bodin de Moraes reconhece uma dupla configuração do mútuo: "Enquanto no mútuo feneratício nada impede a configuração consensual, no mútuo dito gratuito, sem qualquer contraprestação correspectiva, somente a efetiva entrega do bem poderá indicar a vontade dirigida à contratação”. MORAES, Maria Celina Bodin de. O procedimento de qualificação dos contratos e a dupla configuração do contrato de mútuo no direito civil brasileiro. Revista Forense, n. 309. Rio de Janeiro, 1990, p. 60. Para Miguel Maria de Serpa Lopes, "a ideia do contrato consensual em relação ao mútuo evita o contorno que os partidários da sua natureza real são obrigados a fazer, para explicar a fase antecedente à entrega da coisa, por eles considerada como sendo a de um contrato preliminar, que só se integra no definitivo quando, com a entrega da coisa objeto do empréstimo, surge uma segunda fase - a do contrato definitivo". LOPES, Miguel Maria de Serpa. Curso de Direito Civil. Vol. IV. $4^{\mathrm{a}}$ ed. Rio de Janeiro: Freitas Bastos, 1993, p. 361.
} 
"A entrega da coisa, aí, não é elemento necessário à validade do contrato, nem

à sua eficácia; é elemento necessário à sua existência. Sem a entrega da coisa, não há ainda mútuo: o suporte fáctico do negócio jurídico é insuficiente; e não deficiente; tudo se passa no plano da existência, onde o 'não' importa que não se possa pensar em validade ou invalidade, eficácia ou ineficácia. Há o dever e a obrigação de restituir, porque houve o acôrdo e a entrega, de modo que, se o acôrdo foi anterior à entrega, o suporte fáctico só se torna suficiente com a entrega ${ }^{, 28}$.

Sua unilateralidade advém do fato de que o mutuário é o único a contrair obrigações: deverá restituir coisa de mesma espécie, qualidade e quantidade ao final do contrato. Cabe ao mutuante apenas a entrega da coisa no momento de iniciar-se a execução do contrato, mas tal ato é imprescindível para a existência do negócio jurídico em si, não configurando, portanto, obrigação contratual do mutuante ${ }^{29}$.

\section{CAIO MÁRIO DA SILVA PEREIRA esclarece a questão:}

"Somente o mutuário contrai obrigações, uma vez que o mutuante outra não tem senão a de entregar a coisa, ato que, nos contrato ditos reais, integra a sua constituição $^{, 30}$.

Em regra, o contrato de mútuo é gratuito, salvo se tiver finalidade econômica, como prevê o art. 591 do Código Civil ${ }^{31}$. No mútuo oneroso, também chamado de mútuo feneratício ${ }^{32}$, o mutuário, além de se obrigar a

\footnotetext{
${ }^{28}$ MIRANDA, Pontes de. Tratado de Direito Privado: Parte Especial. Tomo XLII. $3^{\mathrm{a}}$ ed. Rio de Janeiro: Borsoi, 1972, p. 8, destacou-se.

${ }^{29}$ Miguel Maria de Serpa Lopes defende a consensualidade do contrato de mútuo e, portanto, argumenta que se trataria de contrato bilateral, sendo a obrigação do mutuante de entregar a coisa decorrente do contrato e não requisito essencial para a sua própria existência. Confira-se: "Considerado, porém, o mútuo um contrato consensual, o seu aspecto jurídico é incontestavelmente sinalagmático, pois, de um lado, encontra-se a obrigação do mutuante de efetuar a tradição da coisa objeto do contrato, enquanto de outro - o mutuário - a de restitui-la". LOPES, Miguel Maria de Serpa. Curso de Direito Civil. Vol. IV. $4^{a}$ ed. Rio de Janeiro: Freitas Bastos, 1993, p. 361 e 362. ${ }^{30}$ PEREIRA, Caio Mário da Silva. Instituições de Direito Civil: Contratos. Vol. III. 12 ${ }^{\mathrm{a}}$ ed. Rio de Janeiro: Forense, 2006, p. 348.

${ }^{31}$ Código Civil, art. 591: "Destinando-se o mútuo a fins econômicos, presumem-se devidos juros, os quais, sob pena de redução, não poderão exceder a taxa a que se refere o art. 406, permitida a capitalização anual."

32 "Toma então o nome de mútuo feneratício ou frutífero, sendo normalmente a título oneroso o mútuo de dinheiro". (GOMES, Orlando. Contratos. 26ª ed. Rio de Janeiro: Forense, 2009, 390).
} 
restituir coisa equivalente, no prazo previamente estipulado, deverá arcar também com o pagamento de juros pelo uso e disposição do bem.

A onerosidade do mútuo não lhe retira o caráter unilateral "porque $a$ obrigação de pagar juros incumbe igualmente ao mutuário"33.

Por sua vez, a temporariedade está atrelada à necessidade de "restituição" de bem com as mesmas características daquele tomado em mútuo, ao final do contrato. Assim não fosse, tratar-se-ia de doação, se gratuito o negócio, ou de compra e venda, se oneroso, mas nunca de mútuo propriamente dito.

Por fim, é característica essencial do contrato de mútuo a transferência da propriedade. Segundo Miguel MARIA DE SERPA LOPES:

"A transferência da propriedade no mútuo não passa de um meio para consecução daquele fim particular, qual seja, o de concessão do gozo que se acolhe pelo uso do dinheiro ou de outras coisas fungíveis. Ao accipiens interessa então não o adquirir da propriedade em si e por si, mas tão-só o direito de gozo que lhe possa proporcionar essa aquisição e durante o tempo contratual, 34 .

No mesmo sentido, PONTES DE MIRANDA:

"No mútuo há a transmissão do direito de propriedade; mas essa transmissão (...) é oriunda de acordo de transmissão, que é ineliminável, muito embora se tenha como elemento do contrato real. (...) O que não há de se esconder é que o mútuo não tem por fito a transferência da propriedade: só se transfere a propriedade porque disso se precisa para se poder dar ao mutuário o gôzo do bem mutuado "35.

A transferência do domínio é, portanto, imprescindível para que a finalidade do mútuo seja atingida, isto é, para que o mutuário possa usar e dispor do bem como se seu fosse. Justamente porque o mútuo, segundo definição de ORLANDO GOMES ${ }^{36}$, é "empréstimo de consumo", decorrendo tal destinação "da qualidade das coisas que podem ser mutuadas", isto é, os bens fungíveis.

\footnotetext{
${ }^{33}$ GOMES, Orlando. Contratos. $26^{\mathrm{a}}$ ed. Rio de Janeiro: Forense, 2009, p. 390.

${ }^{34}$ LOPES, Miguel Maria de Serpa. Curso de Direito Civil. Vol. IV. $4^{\text {a }}$ ed. Rio de Janeiro: Freitas Bastos, 1993, p. 365 e 366.

${ }^{35}$ MIRANDA, Pontes de. Tratado de Direito Privado: Parte Especial. Tomo XLII. $3^{\text {a }}$ ed. Rio de Janeiro: Borsoi, 1972, p. 18.

${ }^{36}$ GOMES, Orlando. Contratos. $26^{\text {a }}$ ed. Rio de Janeiro: Forense, 2009, p. 391.
} 


\title{
1.4. O Equívoco da Nomenclatura e a Confusão dos Institutos
}

A partir da análise dos caracteres jurídicos do contrato de mútuo e das características principais da operação, não restam dúvidas de que o chamado aluguel de ações é, na verdade, um contrato de mútuo.

Isto é, considerando-se que a operação de empréstimo de ações consiste na transferência da propriedade das ações de titularidade do doador ao tomador, que se obriga a pagar àquele uma remuneração pelo uso e disposição das ações, devendo ao final do contrato, entregar ações de mesma espécie, classe e quantidade (tendo em vista que as ações são bens fungíveis), é evidente que estamos diante de mútuo feneratício.

\section{MARCELO TRINDADE esclarece:}

"O chamado 'aluguel de ações' consiste, na verdade, em um contrato de empréstimo, e mais propriamente em um mútuo, isto é, um empréstimo de coisas fungíveis" 37 .

A doutrina atual de GABRIEL LEUTEWILER et al também reconhece a natureza jurídica do empréstimo de ações como sendo um mútuo:

\begin{abstract}
"De fato, as ações listadas em bolsa são bens fungíveis, enquadrando-se no art. 85 do mesmo diploma (...). Podem, portanto, ser objeto de mútuo. Quanto à obrigação, no empréstimo de ações, o tomador deve restituir ao mutuante a quantidade de ações que tomou emprestado, da mesma espécie e qualidade (especificamente no caso das ações, da mesma espécie e classe). Adequa-se perfeitamente, portanto, ao descritivo legal do negócio jurídico corporificado pelo contrato de mútuo" 38 .
\end{abstract}

No mesmo sentido, o então Diretor da CVM Otavio Yazbek em voto proferido no âmbito do Processo Administrativo CVM no SP2011/0304:

"As ações tomadas em empréstimo para posterior utilização pelo tomador e, a menos que ocorra uma coincidência não são os mesmos títulos que serão devolvidos - daí porque elas são inequivocamente coisas fungíveis. $E$ o

\footnotetext{
37 TRINDADE, Marcelo Fernandez. Mútuo de Ações e Insider Trading. In: CASTRO, Rodrigo Rocha Monteiro de; WARDE JÚNIOR, Walfrido Jorge; GUERREIRO, Carolina Dias Tavares (Coord.). Direito Empresarial: e Outros Estudos de Direito em Homenagem ao Professor José Alexandre Tavares Guerreiro. São Paulo: Quartier Latin, 2013, p. 521.

${ }^{38}$ LEUTEWILER, Gabriel; COMIRAN, Giovana Cunha; HAENSEL, Taimi. Aluguel de Ações: Panorama do negócio jurídico, problemas do direito estrangeiro e a eficiência do modelo brasileiro e a questão do voto no direito brasileiro. In: Revista de Direito Mercantil, Industrial, Econômico e Financeiro. São Paulo: Malheiros, n. 161/162, p. 173, jan/ago, 2012.
} 
empréstimo de coisas fungiveis é caracterizado, pelo art. 586 do Código Civil, como mútuo".

Dessa forma, é possível notar que a nomenclatura utilizada no mercado é completamente equivocada ${ }^{39}$. Chamam de aluguel o que na verdade é mútuo.

De fato, não há como se falar em aluguel, uma vez que as ações são bens móveis fungíveis e que a transferência decorrente da operação acarreta a transferência de propriedade para uso e disposição das ações, alcançandose a finalidade do contrato. Na locação de coisa, estamos diante de cessão de uso e gozo de bem infungível, sem que haja a transferência de domínio, assim que não há como confundir os dois institutos.

HENRIQUE VARGAS BELOCH faz, de forma acertada, essa diferenciação:

\begin{abstract}
"Assim, embora chamado vulgarmente de aluguel de ações, o negócio consiste, na sua essência, em um contrato de mútuo, que é justamente o empréstimo de bens fungíveis. Aluguel ou locação jamais, pois estaríamos diante da cessão de uso e gozo de bem não fungível, sem transferência de domínio. No empréstimo de ações fungíveis, ao contrário, o tomador, em razão da fungibilidade, se torna proprietário, considerando que o mútuo transfere o domínio da coisa emprestada. Portanto, aquele que toma ação fungível emprestada poderá vendê-la a terceiro, da mesma forma que se a tivesse adquirido por compra e venda, com a diferença fundamental de que fica obrigado à devolução no vencimento" ${ }^{\text {"40 }}$.
\end{abstract}

No mesmo sentido, GABRIEL LEUTEWILER et al:

"A implicação de, no empréstimo de ações, devolver coisa do mesmo gênero, em igual quantidade e qualidade, e não a própria coisa, demonstra não se tratar de aluguel. No mútuo, ocorre transferência de propriedade, do domínio. Na locação de coisa, é de sua essência a cessão de uso e gozo de coisa não fungível" "4l.

\footnotetext{
${ }^{39} \mathrm{O}$ equívoco é também notado na doutrina estrangeira: "However, despite the impression given by the use of the term, this does not involve actual lending. The shares are transferred in full with an obligation to return the same number of the same shares at a later time". RAAIJMAKERS, Geert T. M. J. Securities Lending and Corporate Governance. Maastricht University Faculty of Law, $\begin{array}{llllll}\text { Forthcoming, } & 2007, & \text { p. } & 1 . & \text { Disponível } & \text { em }\end{array}$ $<$ http://papers.ssrn.com/sol3/papers.cfm?abstract_id=928312>. Acesso em 10/04/2014.

${ }^{40}$ BELOCH, Henrique Vargas. CVM Trata do Empréstimo de Ações em Nova Instrução. $<$ http://www.bmalaw.com.br/nova internet/arquivos/BMA_Review/Newsletter_BMA Review se tembro_outubro_2006_pt.pdf >. Acesso em 03/03/2014.

${ }^{41}$ LEUTEWILER, Gabriel; COMIRAN, Giovana Cunha; HAENSEL, Taimi. Aluguel de Ações: Panorama do negócio jurídico, problemas do direito estrangeiro e a eficiência do modelo brasileiro e a questão do voto no direito brasileiro. In: Revista de Direito Mercantil, Industrial, Econômico e Financeiro. São Paulo: Malheiros, n. 161/162, p. 173, jan/ago, 2012.
} 
Tampouco poder-se-ia falar em comodato, empréstimo gratuito de bens móveis infungíveis. Primeiramente, porque a gratuidade é da essência do contrato de comodato, não podendo ser convencionado o contrário, enquanto que no empréstimo de ações, como mencionado anteriormente, pode ser e, normalmente é, estipulada uma taxa de juros a ser paga pelo mutuário. Em segundo lugar, pela questão da fungibilidade das ações objeto da operação que não se coaduna com o objeto do contrato de comodato.

Por fim, há quem defenda, ainda, tratar-se de depósito irregular, ou seja, depósito de coisas fungíveis, regido pelas mesmas regras aplicáveis ao mútuo, nos termos do art. 645 do Código Civil ${ }^{42}$. Nesse sentido, WALFRIDO JORGE WARDE JR.:

"O empréstimo de ações é, observadas as suas características e funcionalidades, um contrato de depósito irregular. Nele, o depositante, mediante uma remuneração, entrega um bem fungível ao depositário, com a perspectiva de recebê-lo de volta em data futura. (...) Outra característica do depósito irregular é que ele transfere a titularidade da coisa depositada, do depositante ao depositário. Por isso, esse último pode usar, gozar e dispor do bem, desde que o restitua no prazo contratado, com todos os seus frutos, caso assim determine o depositante" ${ }^{43}$.

Tal tese não merece prosperar. Isso porque, como mencionado, o próprio Código determina que o depósito irregular deverá seguir as regras do mútuo, fazendo com que essa distinção perca o sentido.

Esta não é a única razão. Dentre alguns autores, MIGUEL MARIA DE SERPA LOPES defende que o depósito irregular ainda guarda características do depósito comum, uma vez que permite ao depositante que exija a restituição de bens equivalentes a qualquer tempo ${ }^{44}$. Para isso, ainda que o depositante possa usar e dispor da coisa, deve assegurar a disponibilidade da

\footnotetext{
${ }^{42}$ Art. 645. O depósito de coisas fungíveis, em que o depositário se obrigue a restituir objetos do mesmo gênero, qualidade e quantidade, regular-se-á pelo disposto acerca do mútuo.

43 WARDE JR. Walfrido Jorge. $O$ direito é do proprietário. < http://www.capitalaberto.com.br/temas/legislacao-e-regulamentacao/o-direito-e-do-proprietario/>. Acesso em 20/03/2014.

${ }^{44}$ LOPES, Miguel Maria de Serpa. Curso de Direito Civil. Vol. IV. $4^{a}$ ed. Rio de Janeiro: Freitas Bastos, 1993, p. 273.
} 
coisa "de maneira a estar sempre com capacidade de restituir" $"$. O mesmo não ocorre no mútuo, a não ser que previsto de forma expressa no contrato.

A esse respeito, leciona ORLANDO GOMES:

"Mas depósito irregular não é mútuo. Distinguem-se pelo fim econômico. O depósito irregular é feito no interesse do depositante, enquanto o mútuo se faz no interesse do mutuário. Consequências práticas decorrem dessa diversidade de causa. Dentre outras, saliente-se a de que, no depósito irregular, a parte que entrega a coisa pode exigir que seja restituída igual quantidade, em qualquer momento, mesmo que se tenha estipulado prazo fixo para a devolução. Essa possibilidade, própria do depósito, não existe no mútuo, a menos que prevista expressamente" ${ }^{\text {" }}$.

Especificamente com relação à operação de empréstimo de ações, em regra, as partes estipulam previamente o prazo de devolução das ações, podendo o tomador se programar para restituir as ações, e, portanto, mantêlas em carteira, apenas no prazo estabelecido.

Ainda que seja possível, segundo as regras do BTC, incluir previsão de pedido, por parte do mutuante, de restituição antecipada das ações, isso deverá ocorrer dentro de um prazo de até 4 (quatro) dias contados do pedido $(\mathrm{D}+4)$, evidenciando que não é da natureza da operação a manutenção da disponibilidade dos bens fungíveis por parte do mutuário.

\subsection{Tipos de Contrato e Liquidação das Operações}

Com relação ao prazo de vigência, os contratos de empréstimo de ações, segundo as regras do BTC, podem ser de três tipos: (i) contrato por prazo fixo; (ii) contrato com prazo determinado em que o tomador tem a prerrogativa de antecipar a liquidação; (iii) contrato com prazo determinado em que tomador e doador têm a prerrogativa de antecipar a liquidação (o chamado contrato callable).

No primeiro tipo de contrato, como o próprio nome diz, é acordado entre as partes um prazo fixo para a devolução das ações pelo tomador. Nesse

\footnotetext{
${ }^{45}$ LOPES, Miguel Maria de Serpa. Curso de Direito Civil. Vol. IV. $4^{\mathrm{a}}$ ed. Rio de Janeiro: Freitas Bastos, 1993, p. 273.

${ }^{46}$ GOMES, Orlando. Contratos. $26^{\text {a }}$ ed. Rio de Janeiro: Forense, 2009, p. 420.
} 
caso, tanto o doador quanto o tomador deverão permanecer com o empréstimo vigente até a data de vencimento do contrato.

No segundo tipo de contrato, considerado o contrato padrão do BTC, o tomador pode liquidar o empréstimo a qualquer momento, não podendo o devedor encerrar a operação até a data de vencimento do contrato. Nesse caso, o tomador deverá observar o prazo mínimo, estabelecido pela BM\&FBOVESPA, de um dia $(\mathrm{D}+1)$ para liquidar o mútuo, ou, se houver, o prazo de carência estabelecido pelo doador.

Já no terceiro tipo de contrato, atualmente o mais utilizado no Brasil, não apenas o tomador, como também o doador possuem a prerrogativa de liquidar a operação antecipadamente. Uma vez exercida pelo doador a faculdade de solicitar a devolução das ações durante a vigência do empréstimo (isto é, de exercer o call), o tomador terá um prazo de até 4 (quatro) dias úteis, contados do pedido, $(\mathrm{D}+4)$ para providenciar os ativos para devolução.

A operação de mútuo de ações possui liquidação física e financeira. Explique-se: no vencimento do contrato, o tomador deverá devolver ao doador ações de mesma espécie, classe e quantidade (liquidação física), bem como realizar o pagamento da taxa de aluguel previamente estipulada pelas partes (liquidação financeira), devendo ainda pagar emolumentos à BM\&FBOVESPA $^{47}$ e taxas estipuladas pelos intermediários. A liquidação financeira ocorrerá no dia útil seguinte da liquidação física (D+1).

Caso, na data de vencimento do contrato, o mutuário não realize a devolução dos ativos, ele se tornará inadimplente. Diante da inadimplência do tomador, a BM\&FBOVESPA reterá as garantias aportadas por ele no

\footnotetext{
47 “Para empréstimos voluntários, o emolumento é de $0,25 \%$ a.a. sobre o volume da operação, observando um mínimo de R\$10,00. No caso de empréstimos compulsórios, fechados automaticamente pelo BTC para o tratamento de falhas, o emolumento é de 0,50\% a.a., mas nessa situação não há cobrança de valor mínimo”. BM\&FBOVESPA, Folheto BTC, mar 2010, p. 17. http://www.bmfbovespa.com.br/pt-br/Servicos/download/Folheto-BTC.pdf. Acesso em 10 fev. 2014
} 
início do contrato e aplicará uma multa de $0,2 \%$ ao dia sobre o valor dos títulos não devolvidos até sua regularização.

Adicionalmente, o mutuário deverá remunerar o mutuante, até a data da efetiva devolução dos títulos, tomando-se como base de cálculo o dobro da taxa de aluguel originalmente contratada pelas partes ${ }^{48}$.

Na hipótese de a inadimplência persistir, a BM\&FBOVESPA poderá determinar a recompra automática dos ativos, podendo, inclusive, executar as garantias prestadas pelo tomador a fim de pagar a recompra, caso necessário.

Por fim, na remota hipótese de indisponibilidade dos ativos em mercado (por conta da baixa liquidez), tornando impossível a aquisição das ações para posterior devolução, a BM\&FBOVESPA poderá determinar a liquidação financeira da operação. Nesse caso, a cotação utilizada pela Câmara de Ações corresponderá ao maior valor obtido entre (a) a média das cotações médias à vista, verificadas nas 30 (trinta) últimas sessões de negociação; ou (b) a cotação média à vista verificada no dia do vencimento da operação de empréstimo ${ }^{49}$.

Tendo sido analisados os principais contornos da operação e definida a sua natureza jurídica, serão examinados no próximo capítulo os principais direitos políticos e patrimoniais conferidos, pela Lei das S.A., aos acionistas a fim de que seja identificado como tais direitos se relacionam dentro da operação de mútuo de ações.

\footnotetext{
48 BM\&FBOVESPA, Folheto BTC, mar 2010, p. 17. http://www.bmfbovespa.com.br/ptbr/Servicos/download/Folheto-BTC.pdf. Acesso em 10 fev. 2014

${ }^{49}$ Não tendo ocorrido negociação daquelas ações nos períodos de que tratam as hipóteses (a) e (b) acima, a cotação utilizada será a última cotação média da ação praticada no mercado à vista.
} 


\section{Capítulo II \\ Principais Direitos Políticos e Patrimoniais \\ dos Acionistas}

A condição de acionista de uma sociedade anônima implica na obtenção de uma série de direitos e deveres. Os direitos que lhe são conferidos, por sua vez, poderão ser essenciais ou modificáveis ${ }^{50}$.

A Lei das S.A., em seu art. 109, enumera os direitos essenciais assegurados aos acionistas, que não poderão ser afastados pela assembleia geral ou pelo estatuto social. São eles: (i) o direito de participar dos lucros sociais; (ii) o direito de participar do acervo da companhia, em caso de liquidação; (iii) o direito de fiscalizar, na forma prevista em lei, a gestão dos negócios sociais; (iv) o direito de preferência para subscrição de ações e outros valores mobiliários conversíveis em ações; e (v) o direito de retirar-se da sociedade nos casos previstos em lei.

Os direitos essenciais dos acionistas são assim denominados, tendo em vista sua inderrogabilidade e irrenunciabilidade ${ }^{51}$. Isto é, ainda que o acionista opte por, eventualmente, não exercer o seu direito, isso não importará em renúncia, tampouco em consentimento à derrogação do direito $^{52}$.

Note-se que o direito de voto não se encontra na categoria de direitos essenciais - sendo, portanto, modificável -, uma vez que pode ser suprimido ou restringido, pelo estatuto social, em troca de alguma preferência ou vantagem patrimonial a ser atribuída às ações preferenciais.

NELSON EIZIRIK esclarece a questão:

"O direito de voto não foi incluido entre os direitos essenciais previstos no artigo 109. Tal ausência é explicada pelo fato de se permitir que o estatuto deixe de

\footnotetext{
${ }^{50}$ BORBA, José Edwaldo Tavares. Direito Societário. 6a ed. Rio de Janeiro: Renovar, 2001, p. 299.

${ }^{51}$ BARBOSA, Marcelo. Direitos dos Acionistas. In: LAMY FILHO, Alfredo; PEDREIRA, José Luiz Bulhões. Direito das Companhias. Vol. I. Rio de Janeiro: Forense, 2009, p. 304.

${ }^{52}$ EIZIRIK, Nelson. A Lei das S.A. Comentada. Vol. I. São Paulo: Quartier Latin, 2011, p. 589.
} 
atribuí-lo aos titulares de ações preferenciais ou o confira com restrições. Assim, seguindo o sistema anterior, o direito de voto inclui-se na categoria dos direitos reservados a certos acionistas" $" 53$.

Para o presente trabalho, dentre os direitos essenciais previstos no art. 109, apenas o direito de participar dos lucros, o direito de preferência para subscrição de ações e o direito de retirar-se da sociedade serão analisados, assim como o direito de voto.

\section{1. $\quad$ Direito de Participar dos Lucros}

O direito de participar dos lucros é o direito patrimonial de maior relevância conferido aos acionistas e está atrelado à perquirição do fim econômico para o qual uma sociedade anônima é constituída: a obtenção de lucros, como bem destaca o art. $2^{\circ}$ da Lei das S.A ${ }^{54}$.

Segundo TUlLIO ASCARELlI ${ }^{55}$, o contrato plurilateral, ato de constituição da sociedade anônima, é justamente contrato de "comunhão de fim", uma vez que os acionistas unem-se a fim de atingir um objetivo em comum, qual seja, o de que a sociedade produza lucros e distribua-os entre seus acionistas.

Nesse sentido, MARCELO BARBOSA:

"Se o que caracteriza as companhias é a finalidade lucrativa (art. $2^{\circ}$ ), e se tais sociedades são instrumentos criados pelos acionistas com a finalidade de auferir resultados econômicos a serem por eles percebidos, é lícito entender que se trata de direito diretamente ligado à finalidade empresarial que congrega os acionistas, enquanto os demais direitos seriam, de certa maneira, meios para viabilizar o funcionamento adequado das atividades da sociedade"

A distribuição de lucros aos acionistas se dá, em regra ${ }^{57}$, na forma de dividendos e depende, para tanto, (i) da apuração de lucros, (ii) de deliberação em assembleia geral que declare os dividendos e determine a sua

\footnotetext{
${ }^{53}$ Ibid., p. 625.

${ }^{54}$ Art. $2^{\circ}$ Pode ser objeto da companhia qualquer empresa de fim lucrativo, não contrário à lei, à ordem pública e aos bons costumes.

${ }_{55}$ ASCARELLI, Tullio. O Problema das Sociedades Anônimas e Direito Comparado. São Paulo: Saraiva \& Cia, 1945, p. 327.

${ }^{56}$ BARBOSA, Marcelo. Direitos dos Acionistas. In: LAMY FILHO, Alfredo; PEDREIRA, José Luiz Bulhões (Coords.). Direito das Companhias. Vol. I. Rio de Janeiro: Forense, 2009, p. 306.

${ }^{57}$ Poderá ser também na forma de juros sobre capital próprio.
} 
distribuição e, por fim, (iii) do efetivo pagamento da companhia dos dividendos declarados a seus acionistas.

Ainda que seja o fim da atividade empresarial, a produção de lucros não é um resultado necessário, mas evidentemente aleatório, uma vez que a ideia de risco é inerente à própria noção de empresa ${ }^{58}$. Como bem ressaltou LuIZ ANTÔNIO DE SAMPAIO CAMPOS, "a possibilidade de insucesso empresarial faz parte da regra do jogo" ${ }^{59}$.

No entanto, mesmo que não haja lucro a ser distribuído, o direito do acionista de participar dos lucros sociais não se extingue, uma vez que irrenunciável e inderrogável. Trata-se, portanto, “de um direito de participação e por isso de caráter permanente, de que não decai o acionista pela falta de ocorrência de evento que impeça a sua efetivação, em determinados exercícios" $" 60$. Seu direito permanece intacto, tornando-se exigível quando, de fato, houver lucros.

Uma vez apurada a existência de lucro líquido e deliberada em assembleia geral a sua distribuição na forma de dividendos, os acionistas passam a deter um direito de crédito contra a companhia, que deverá ser pago na data estabelecida na própria assembleia geral.

Em se tratando de ações custodiadas em instituição financeira, a companhia deverá efetuar o pagamento à própria instituição a quem caberá repassar os valores ao acionista titular das ações depositadas.

NELSON EIZIRIK define de forma bem sintética e precisa o direito de participação nos lucros como um direito "subjetivo, individual, de caráter econômico, irrenunciável e irrevogável do acionista, que se converte em

\footnotetext{
${ }^{58}$ COMPARATO, Fábio Konder. Direito Empresarial: Estudos e Pareceres. São Paulo: Saraiva, 1995, p. 161.

${ }^{59}$ CAMPOS, Luiz Antônio de Sampaio. Utilização do Lucro do Exercício: Dividendo e Recompra. In: ADAMEK, Marcelo Vieira Von (Coord.). Temas de Direito Societário e Empresarial Contemporâneos. São Paulo: Malheiros, 2011, p. 426.

${ }^{60}$ CARVALHOSA, Modesto. Comentários à Lei de Sociedades Anônimas. Vol. II. $5^{\text {a }}$ ed. São Paulo: Saraiva, 2011, p. 390.
} 
direito de crédito contra a companhia quando a assembleia geral delibera sua distribuição" ${ }^{\prime 61}$.

Nos termos do art. 205 da Lei das S.A., terão direito ao recebimento de dividendos os acionistas que forem titulares ou usufrutuários das ações na data da declaração dos dividendos em assembleia geral. Ou seja, ainda que, posteriormente, tais ações sejam alienadas a terceiros, os dividendos serão devidos e pagos àquele que era titular ou usufrutuário da ação na data da declaração. A partir desse momento, as ações passam a ser denominadas ex dividendos.

O fato de o usufrutuário fazer jus ao recebimento de dividendos está relacionado à própria natureza do dividendo, que constitui um fruto civil e, portanto, de acordo com o art. 1.394 do Código Civil ${ }^{62}$, pertence sempre ao usufrutuário.

A Lei das S.A. estabelece uma exceção com relação ao disposto no Código Civil com relação ao titular dos frutos quando cessar o usufruto. Isso porque o art. 1.398 do Código Civil ${ }^{63}$ estabelece que os frutos civis, vencidos na data inicial do usufruto, pertencem ao proprietário, e ao usufrutuário os vencidos na data em que cessa o usufruto.

Ocorre que no caso do pagamento de dividendos, a Lei das S.A. deixa claro que será titular do direito a receber dividendos aquele que for proprietário ou usufrutuário das ações na data de sua declaração. Ou seja, extinto o usufruto antes da realização da assembleia que declara os dividendos, caberá ao nu-proprietário o recebimento dos proventos, ainda que correspondente a um exercício em que o usufruto estivesse em vigor.

\footnotetext{
${ }^{61}$ EIZIRIK, Nelson. A Lei das S.A. Comentada. Vol. I. São Paulo: Quartier Latin, 2011, p. 595.

${ }^{62}$ Código Civil: "Art. 1.394. O usufrutuário tem direito à posse, uso, administração e percepção dos frutos".

63 Código Civil: "Art. 1.398. Os frutos civis, vencidos na data inicial do usufruto, pertencem ao proprietário, e ao usufrutuário os vencidos na data em que cessa o usufruto".
} 
Isso porque "o direito de crédito dos acionistas ao dividendo não surge do balanço de encerramento do exercício, mas da aprovação pela assembleia geral e da deliberação de destinar os lucros, ou parte deles, ao pagamento de dividendos" $"$.

\subsection{Direito de Preferência Para Subscrição de Ações}

O direito de preferência para subscrição de ações trata-se de direito patrimonial conferido aos acionistas com o objetivo de, ante um aumento de capital, garantir a manutenção da proporção de sua participação no capital social. Constitui, portanto, "elemento indispensável à preservação do status ou posição jurídica do acionista na companhia"65.

Com isso, o exercício do direito permite ao acionista evitar a diluição de sua participação acionária decorrente de aumento de capital.

O termo "direito de preferência" é altamente criticado pela doutrina. Segundo FÁBIO KONDER COMPARATO, "a expressão é tecnicamente deficiente, pois não se trata de simples prelação ou preferência e, sim, de autêntica opção"

Na visão do autor, tratar-se-ia de uma opção, pois, o acionista não fica submetido a uma concorrência de ofertas, mas possui um direito exclusivo de subscrever as ações, dentro de um prazo decadencial estabelecido pela Lei das S.A. (que não poderá ser inferior a 30 dias, nos termos do $\S 4^{\circ}$ do art. 171).

Assim, ainda que a companhia receba ofertas mais vantajosas de terceiros, não poderá aceitá-las até o decurso do prazo decadencial no qual o acionista poderá manifestar o interesse em exercer o seu direito. Não manifestado o interesse, permitirá a subscrição por terceiros.

\footnotetext{
${ }^{64}$ EIZIRIK, Nelson. A Lei das S.A. Comentada. Vol. III. São Paulo: Quartier Latin, 2011, p. 129. ${ }^{65}$ COMPARATO, Fábio Konder. Novos Ensaios e Pareceres de Direito Empresarial. Rio de Janeiro: Forense, 1981, p. 178.

${ }^{66}$ Ibid., p. 176 e 177.
} 
É diferente, por exemplo, do direito de preferência contratual, previsto em muitos acordos de acionistas, no qual o signatário do acordo, diante de oferta de terceiro para a aquisição de ações objeto do contrato, terá preferência para aquisição daquelas ações desde que, no mínimo, em condições iguais às da oferta de terceiro.

Portanto, preferência ocorreria caso, diante de aumento de capital, terceiros pudessem, concorrentemente, subscrever as ações, e os então acionistas tivessem preferência para cobrir as propostas.

\section{PONTES DE MIRANDA explica:}

"O direito de opção é expediente de proteção aos acionistas. Poderia haver direito de preferência, mas teria o inconveniente de sujeitar os novos subscritores a exporse a subscrever e ter de ser cancelada a sua subscrição em virtude do exercício do direito de preferência por parte dos acionistas ${ }^{, 67}$.

Trata-se, portanto, de verdadeiro poder, direito subjetivo potestativo conferido ao acionista ${ }^{68}$.

Ultrapassada essa questão, o direito de opção para subscrição de ações, ao garantir a manutenção da participação acionária, visa a assegurar proteção não somente aos direitos patrimoniais - uma vez que garante ao acionista não ver reduzida sua quota parte na distribuição de dividendos como também indiretamente aos direitos políticos, tendo em vista que a Lei das S.A. exige percentuais mínimos para o exercício de determinados direitos de participação e de fiscalização ${ }^{69}$. Acaba por ser relevante até mesmo para fins de controle acionário.

\section{LUIZ ALBERTO COLONNA ROSMAN enfatiza tal questão:}

"O direito de preferência é também essencial na preservação dos direitos políticos do acionista, pois sua capacidade de influir nas deliberações das assembleias gerais depende do número de votos que exerce e há direitos que pressupõem a titularidade de uma porcentagem mínima de ações, como os de eleger membros do

\footnotetext{
${ }^{67}$ MIRANDA, Pontes de. Tratado de Direito Privado. Tomo L. $3^{\mathrm{a}}$ ed. Rio de Janeiro: Borsoi, 1972, p. 352.

${ }^{68}$ Reconhece-se que o direito de preferência também teria essa mesma natureza.

${ }^{69}$ EIZIRIK, Nelson. A Lei das S.A. Comentada. Vol. I. São Paulo: Quartier Latin, 2011, p. 604 e 605.
} 
Conselho de Administração e do Conselho Fiscal, convocar Assembleia Geral, pedir a exibição de livros etc. " $"$.

De certa forma, portanto, o exercício do direito essencial de opção para subscrição de ações protege, ainda que indiretamente, outros direitos essenciais dos acionistas, como o direito a participação nos lucros, o direito a participação no acervo líquido em caso de liquidação e até mesmo o direito de fiscalizar a gestão dos negócios sociais ${ }^{71}$.

Na visão de FÁBIO KONDER COMPARATO, seria, ainda, uma forma de compensar os acionistas pela desvalorização da ação em razão do excesso de oferta:

“(...) Toda a emissão nova de ações - seja com ingresso de novos recursos na companhia, seja com a capitalização de reservas e lucros, ou com a realização de ativos - acarreta, em princípio, uma pressão baixista na cotação das ações no mercado, pelo acréscimo de oferta desses papéis em relação à demanda existente. Por conseguinte, a aquisição das ações de nova emissão deve representar, para o acionista, uma forma de compensação pela perda, ainda que momentânea, de valor do seu investimento acionário primitivo, no mercado "72.

Diferentemente do direito a dividendos, o direito de preferência não tem natureza de frutos $^{73}$, e, portanto, o seu titular é o nu-proprietário. Com relação ao usufrutuário, a Lei das S.A. estabeleceu que poderá exercer o direito de preferência legal para subscrever ações nos 10 (dez) últimos dias do prazo decadencial, caso o nu-proprietário não o faça. A lei indica, portanto, quem está legitimado a exercer o direito e em que momento poderá fazê-lo.

Subscritas as ações pelo usufrutuário, este adquirirá as novas ações em nome próprio, tornando-se, automaticamente, seu titular. Subscritas pelo nu-

\footnotetext{
${ }^{70}$ ROSMAN, Luiz Alberto Colonna. Modificação do Capital Social. In: LAMY FILHO, Alfredo; PEDREIRA, José Luiz Bulhões. Direito das Companhias. Vol. II. Rio de Janeiro: Forense, 2009, p. 1425 .

${ }^{71}$ COMPARATO, Fábio Konder. Novos Ensaios e Pareceres de Direito Empresarial. Rio de Janeiro: Forense, 1981, p. 178 e 179.

${ }^{72}$ Ibid., p. 179.

${ }^{73}$ Segundo Pontes de Miranda, "o direito de opção dos acionistas não é fruto, mas é direito que se irradia das ações". MIRANDA, Pontes de. Tratado de Direito Privado: Parte Especial. Tomo L. $3^{\text {a }}$ ed. Rio de Janeiro: Borsoi, 1972, p. 361.
} 
proprietário, salvo estipulação em contrário, adquire este as novas ações sem quaisquer restrições, uma vez que passam a integrar seu patrimônio ${ }^{74}{ }_{-}^{75}$.

Importante mencionar que o direito de preferência pode ser objeto de cessão, caso assim seja a vontade do acionista, nos termos do $§ 6^{\circ}$ do art. 171 da Lei das S.A ${ }^{76}$. O próprio art. $2^{\circ}$ da Lei $n^{\circ} 6.385 / 76$ define-o como um valor mobiliário ao estabelecer, em seu inciso II, que serão considerados valores mobiliários os direitos relativos aos valores mobiliários constantes do inciso I (dentre eles, as ações).

Nesse sentido, leciona NELSON EIZIRIK:

"Os acionistas podem livremente ceder o seu direito de preferência. Trata-se, portanto, de um direito que pode ser transacionado autonomamente, constituindo um valor mobiliário dotado de livre negociabilidade no mercado de capitais "'77.

Luiz ALberto COLONNA ROSMAN compartilha do mesmo entendimento, ressaltando que a cessão só poderá ocorrer diante de um aumento de capital em concreto:

"O acionista pode ceder o seu direito de preferência (art. 171, $\S 6^{\circ}$ ), de forma a que nos aumentos de capital mediante subscrição de ações, o acionista que não queira, ou não possa, exercê-lo, tem a faculdade de negociar seu direito transferindo-o, gratuita ou onerosamente, a outro acionista ou a terceiro. $\boldsymbol{O}$ que pode ser cedido é o direito de preferência relativo a aumento de capital em concreto, já deliberado, e não o direito em abstrato"

Isso porque, segundo NELSON EIZIRIK ${ }^{79}$, o direito de preferência seria, na verdade, mera expectativa de direito, que só se materializaria com a deliberação do aumento de capital.

\footnotetext{
${ }^{74}$ EIZIRIK, Nelson. A Lei das S.A. Comentada. Vol. II. São Paulo: Quartier Latin, 2011, p. 516 e COMPARATO, Fábio Konder. Novos Ensaios e Pareceres de Direito Empresarial. Rio de Janeiro: Forense, 1981, p. 196 e 197.

${ }^{75}$ Em sentido contrário: “(...) a concepção do direito brasileiro é a de ser irradiado das ações e não da qualidade de sócio, o direito de opção. O usufruto estende-se, por isso, às novas ações. Se não convém ao dono subscrever, pode subscrever o usufrutuário, que também perde o domínio da quantia que inverteu com a subscrição". MIRANDA, Pontes de. Tratado de Direito Privado. Tomo L. $3^{\text {a }}$ ed. Rio de Janeiro: Borsoi, 1972, p. 361.

${ }^{76}$ Lei das S.A.: Art. $171, \S 6^{\circ}$ "O acionista poderá ceder seu direito de preferência".

${ }^{77}$ EIZIRIK, Nelson. A Lei das S.A. Comentada. Vol. I. São Paulo: Quartier Latin, 2011, p. 605.

${ }^{78}$ ROSMAN, Luiz Alberto Colonna. Modificação do Capital Social. In: LAMY FILHO, Alfredo; PEDREIRA, José Luiz Bulhões. Direito das Companhias. Vol. II. Rio de Janeiro: Forense, 2009, p. 1436, destacou-se.

${ }^{79}$ EIZIRIK, Nelson. A Lei das S.A. Comentada. Vol. II. São Paulo: Quartier Latin, 2011, p. 510.
} 
Também, na visão de PONTES DE MIRANDA, o direito de preferência só poderia ser cedido após deliberado o aumento de capital, mas porque, a seu ver, o contrário resultaria em violação ao direito de igualdade entre os acionistas:

"A solução acertada é a que somente considera cessivel o direito depois de deliberado o aumento, porque, então, não se ofende o princípio do igual tratamento dos acionistas, no tocante à sua participação nas deliberações da assembleia geral: a cessão antes não retiraria o voto, mas esvaziaria, de certo modo, o auto-regramento da vontade. Publicada a deliberação, há a cessibilidade" ${ }^{, 80}$.

Por fim, ainda que seja um direito essencial, o direito de preferência legal para subscrição de ações poderá ser afastado pelo estatuto de companhia aberta com capital autorizado caso, nos termos do art. 172 da Lei das S.A., a colocação dos valores mobiliários seja feita mediante venda em bolsa ou subscrição pública ou permuta por ações, em oferta pública de aquisição de controle, nos termos dos arts. 257 e 263 . A própria lei afasta o direito de preferência no caso de opções de ações outorgadas a administradores e, portanto, relativiza diretamente e admite relativização do direito essencial.

\subsection{Direito de Retirada}

O direito de retirar-se da sociedade, também conhecido como direito de recesso, é um direito político conferido pela Lei das S.A. que busca compensar a relativização que o princípio majoritário impõe à intangibilidade dos contratos no âmbito da companhia ${ }^{81}$.

Isto é, ele vem como uma forma de equilibrar, de um lado, o princípio majoritário, que determina que os titulares da maioria do capital votante comandem, no interesse da companhia, as deliberações sociais e, de outro, o interesse dos acionistas dissidentes que não devem ser obrigados a

\footnotetext{
${ }^{80}$ MIRANDA, Pontes de. Tratado de Direito Privado. Tomo L. $3^{\text {a }}$ ed. Rio de Janeiro: Borsoi, 1972, p. 367.

${ }^{81}$ BARBOSA, Marcelo. Direitos dos Acionistas. In: LAMY FILHO, Alfredo; PEDREIRA, José Luiz Bulhões (Coords.). Direito das Companhias. Vol. I. Rio de Janeiro: Forense, 2009, p. 303.
} 
permanecer em uma "companhia essencialmente distinta daquela na qual ingressaram"82.

Assim, diante de uma deliberação social na qual tenham seus interesses contrariados, os acionistas minoritários dissidentes poderão, nos casos previstos em lei, retirar-se da companhia, mediante o recebimento do valor de reembolso de suas ações ${ }^{83}$.

A deliberação que contraria os interesses dos minoritários não é, de forma alguma, ato ilícito. Como bem destaca FÁBIO KONDER COMPARATO, "o direito de recesso do sócio da deliberação social não constitui uma sanção de ato ilícito praticado pela maioria; não representa uma forma de indenização" 84 .

Inclusive porque, se assim fosse, a lei estaria autorizando a companhia a praticar atos ilícitos, desde que indenizasse os acionistas cujos interesses foram contrariados ${ }^{85}$ - o que claramente não é o caso. Como dito, trata-se apenas de compensação pela sobreposição do interesse social aos interesses particulares prejudicados diante de uma alteração relevante na estrutura da companhia.

É importante notar que o direito de recesso é estritamente taxativo, não podendo o estatuto ou a assembleia geral ampliar ou restringir as hipóteses em que tal direito poderá ser exercido ${ }^{86}$.

\footnotetext{
${ }^{82}$ EIZIRIK, Nelson. A Lei das S.A. Comentada. Vol. I. São Paulo: Quartier Latin, 2011, p. 606.

${ }^{83}$ Art. $45, \S 1^{\circ}$ - O estatuto pode estabelecer normas para a determinação do valor de reembolso, que, entretanto, somente poderá ser inferior ao valor de patrimônio líquido constante do último balanço aprovado pela assembléia-geral, observado o disposto no $\S 2^{\circ}$, se estipulado com base no valor econômico da companhia, a ser apurado em avaliação $\left(\S \S 3^{\circ}\right.$ e $\left.4^{\circ}\right)$.

${ }^{84}$ COMPARATO, Fábio Konder. Valor de Reembolso no Recesso Acionário. In: Revista dos Tribunais. São Paulo: Revista dos Tribunais, v. 563, setembro, ano 71, 1982, p. 50.

85 PEDREIRA, Luis Eduardo Bulhões. Direito de Retirada. In: LAMY FILHO, Alfredo; PEDREIRA, José Luiz Bulhões (Coords.). Direito das Companhias. Vol. I. Rio de Janeiro: Forense, 2009 , p. 341.

${ }^{86}$ Nesse sentido, "Por ser entendimento da doutrina o de que as causas do recesso devem ser a exceção, e não a regra, também é entendimento da doutrina majoritária considerar as causas de recesso existentes como causas taxativas, que não comportam qualquer interpretação extensiva". MUSSNICH, Francisco A. Maciel. Reflexões sobre o Direito de Recesso na Lei das Sociedades por Ações. In: LOBO, Jorge (coord.). Reforma da Lei das Sociedades Anônimas: Inovações e Questões Controvertidas da Lei $n^{o} 10.303$, de 31.10.2001. $2^{\text {a }}$ ed. Rio de Janeiro: Forense, 2002, p. 297; “A
} 
Trata-se de nítido direito de exceção: ao invés de o acionista dissidente alienar suas ações da forma usual - privadamente ou em bolsa -, retirando seu investimento na companhia, ele demanda da sociedade o desembolso de altas quantias para o pagamento do reembolso do valor de suas ações.

\section{ALFREDO LAMY FILHO e JosÉ LuIZ BulHÕES PEDREIRA, coautores da} Lei das S.A., destacam tal caráter:

"A lei somente prevê direito de retirada em alguns casos expressos, de deliberações que modificam de modo fundamental a organização da companhia ou os direitos de participação dos acionistas, porque o reembolso de ações pãe em risco a continuidade e viabilidade do funcionamento da empresa, cuja preservação - e por motivos de interesse geral, econômico e social - um dos principais objetivos da lei. $\underline{O}$ direito de retirada é, portanto, excepcional, e por ser capaz de prejudicar o interesse geral há de ser interpretado de modo estrito ${ }^{87}$.

\section{No mesmo sentido, NELSON EIZIRIK:}

"O direito de retirada apresenta natureza excepcional, uma vez que, (i) como é a própria companhia que deve arcar com o pagamento do reembolso devido ao acionista dissidente, o seu exercício pode colocar em risco a saúde financeira da sociedade, além de impedir ou dificultar mudanças estruturais necessárias ao desenvolvimento da empresa; e (ii) constitui medida que privilegia o interesse $\underline{\text { individual do acionista dissidente em detrimento do interesse social }}^{\text {"88. }}$.

Segundo LUIS EDUARDO BULHÕES PEDREIRA, a excepcionalidade do direito de retirada decorre da natureza dos interesses que protege:

\footnotetext{
enumeração das hipóteses que ensejam o direito de recesso reveste-se do caráter de numerus clausus, não se permitindo a extensão do recesso a circunstâncias outras não incluídas no mencionado elenco". TEIXEIRA Egberto Lacerda; GUERREIRO, José Alexandre Tavares. Das Sociedades Anônimas no Direito Brasileiro. Vol. I. São Paulo: José Bushatsky, 1979, p. 286; “Em consequência, não se admite exista direito de recesso em hipóteses análogas às previstas na lei. Ademais, não pode o estatuto acrescer outros casos em que o direito de recesso seria admitido". CARVALHOSA, Modesto. Comentários à Lei das Sociedades Anônimas. Vol. I. São Paulo: Saraiva, 1977, p. 233.

${ }^{87}$ LAMY FILHO, Alfredo; PEDREIRA, José Luiz Bulhões. A Lei das S.A. Vol. II. $2^{\mathrm{a}}$ ed. Rio de Janeiro: Renovar, 1996, p. 340, destacou-se.

${ }^{88}$ EIZIRIK, Nelson. A Lei das S.A. Comentada. Vol. I. São Paulo: Quartier Latin, 2011, p. 606, destacou-se.
} 
"O reembolso de ações pode implicar redução do capital social, instituto fundamental da companhia, de que dependem os direitos dos credores e a própria funcionalidade de sociedade que pode ter milhares e até milhões de acionistas em permanente substituição; e o direito de retirada excepciona o princípio de que o capital social não pode ser restituído aos acionistas em prejuízo dos credores sociais. $O$ exercício do direito de retirada pode, também, constituir óbice a mudancas necessárias à sobrevivência ou à expansão da companhia se esta não tem capacidade de pagar o valor de reembolso aos acionistas dissidentes

As hipóteses taxativas que ensejam o direito de recesso estão previstas no art. 137 da Lei das S.A., que faz referência ao art. 136, bem como esparsas em outros dispositivos da lei e podem ser divididas em duas categorias: (i) as que alteram significativamente a estrutura organizacional da companhia; e (ii) as que reduzem direitos de participação dos acionistas ${ }^{90}$.

Com relação à primeira categoria, temos as seguintes deliberações: (i) fusão da companhia ou a sua incorporação em outra (art. 136, inciso IV); (ii) participação em grupo de sociedades (art. 136, inciso V); (iii) mudança do objeto social (art. 136, inciso VI); (iv) cisão da companhia, se importar mudança do objeto social, redução do dividendo obrigatório ou participação em grupo de sociedades (art. 136, inciso IX c/c art. 137, inciso III); (v) transformação em outro tipo societário, caso previsto no estatuto que a deliberação se dará por maioria (art. 221); (vi) não abertura de capital de sociedade sucessora de companhia aberta envolvida em operação de fusão, incorporação ou cisão (art. 223, § 4º); (vii) aquisição de controle acionário por pessoa jurídica de direito público em virtude de desapropriação de ações (art. 236, parágrafo único); (viii) incorporação de ações (art. 252, § $1^{\text {o }}$ ); e (ix)

\footnotetext{
89 PEDREIRA, Luis Eduardo Bulhões. Direito de Retirada. In: LAMY FILHO, Alfredo; PEDREIRA, José Luiz Bulhões (Coords.). Direito das Companhias. Vol. I. Rio de Janeiro: Forense, 2009, p. 330, destacou-se.

${ }^{90}$ A esse respeito: LAMY FILHO, Alfredo; PEDREIRA, José Luiz Bulhões. A Lei das S.A. Vol. II. $2^{\mathrm{a}}$ ed. Rio de Janeiro: Renovar, 1996, p. 340; EIZIRIK, Nelson. A Lei das S.A. Comentada. Vol. I. São Paulo: Quartier Latin, 2011, p. 607; e PEDREIRA, Luis Eduardo Bulhões. Direito de Retirada. In: LAMY FILHO, Alfredo; PEDREIRA, José Luiz Bulhões (Coords.). Direito das Companhias. Vol. I. Rio de Janeiro: Forense, 2009, p. 341.
} 
aquisição de controle de outra sociedade mercantil quando o preço de aquisição ultrapassar os parâmetros previstos na Lei das S.A. (art. $256, \S 2^{\circ}$ ).

Com relação à segunda categoria, temos as seguintes deliberações: (i) criação de ações preferenciais ou aumento de classes de ações preferenciais sem guardar proporção com as demais classes de ações preferenciais, salvo se já autorizado pelo estatuto social (art. 136, inciso I); (ii) alteração nas preferências, vantagens e condições de resgate ou amortização de 1 (uma) ou mais classes de ações preferenciais (art. 136, inciso II); (iii) criação de nova classe de ações preferenciais mais favorecida (art. 136, inciso II); e (iv) redução do dividendo obrigatório (art. 136, inciso III).

Sendo exceção, o direito de retirada não pode jamais representar uma oportunidade de negócio para os acionistas e essa é uma das maiores preocupações doutrinárias a respeito do exercício de tal direito, principalmente em companhias abertas.

A esse respeito, LUIZ ANTONIO DE SAMPAIO CAMPOS leciona:

"Na companhia aberta, a possibilidade do uso disfuncional do recesso como oportunidade de negócio é infinitamente maior e, portanto, objeto de maior preocupação. Isto porque se, de um lado, quando o valor do recesso é inferior ao valor de bolsa, o recesso passa a ser teórico, ressalvada a ausência de liquidez, uma vez que o investidor fatalmente, mesmo divergindo intrinsicamente da operação, já estará protegido e preferirá sempre alienar suas ações no mercado ao invés de exercer o recesso. De outro lado, porém, como as ações são negociadas diariamente no mercado e apresentam cotação visível, muitas vezes os acionistas, principalmente os acionistas profissionais, enxergam no direito de recesso uma oportunidade de negócio e não um dissenso com relação à deliberação tomada. É que toda vez que o valor das ações pelo cálculo do valor de reembolso é superior ao valor de mercado das acões, tem-se um fortíssimo incentivo econômico-mas não uma razão jurídica-para que o recesso seja exercido, não só por representar um ganho imediato, mas também porque possibilita até mesmo que, com parte 
dos recursos recebidos em reembolso, novamente se readquira acões da companhia no mercado "91.

Assim, muitas vezes diante de uma perspectiva de ganho econômico por meio do exercício do direito de recesso - uma vez que o valor do reembolso apresenta-se superior ao valor da cotação das ações - os acionistas, de forma abusiva, dissentem da deliberação assemblear, ainda que dela não discordem ou saibam que se dará no interesse da companhia.

Foi justamente com o fim de evitar a chamada "indústria do recesso" que a Lei das S.A. estabeleceu que algumas hipóteses de retirada devem obedecer a determinados critérios.

Por exemplo, no caso das hipóteses (i) a (iii) da segunda categoria, somente terão direito de retirada os titulares de ações de espécie ou classe prejudicadas. Ou seja, é necessário que o acionista demonstre que a deliberação tomada lhe trará efetivo prejuízo para que possa retirar-se da companhia mediante o reembolso de suas ações.

Da mesma forma, no caso de fusão de companhia ou sua incorporação em outra e participação em grupo de sociedades, não terão direito de retirada os titulares de ação de espécie e classe que tenha liquidez e dispersão no mercado. Os conceitos de liquidez e dispersão são definidos pela própria lei.

Haverá liquidez quando a espécie ou classe de ação "integre índice geral representativo de carteira de valores mobiliários admitido à negociação no mercado de valores mobiliários, no Brasil ou no exterior, definido pela Comissão de Valores Mobiliários". A área técnica da CVM, por meio do Ofício Circular SEP n ${ }^{\circ} 01 / 2014$, firmou entendimento ${ }^{92}$ de que

\footnotetext{
${ }^{91}$ CAMPOS, Luiz Antonio de Sampaio. Notas sobre o Direito de Recesso e a Exigência de Titularidade Ininterrupta (Art. 137, $\S 1^{\circ}$ ). In: CASTRO, Rodrigo R. Monteiro de; WARDE JR., Walfrido Jorge; GUERREIRO, Carolina Dias Tavares (Coords.). Direito Empresarial e Outros Estudos de Direito em Homenagem ao Professor José Alexandre Tavares Guerreiro. São Paulo: Quartier Latin, 2013, p. 246, destacou-se.

${ }^{92}$ Fruto de decisões do Colegiado da autarquia.
} 
“os índices considerados para efeito de liquidez devem ser aqueles admitidos à negociação em bolsas de futuros, atualmente, Ibovespa e IBrX-50”.

Por sua vez, haverá dispersão "quando o acionista controlador, a sociedade controladora ou outras sociedades sob seu controle detiverem menos da metade da espécie ou classe da ação". Isto é, quando haja ações em circulação no mercado suficientes para viabilizar uma negociação no mercado.

A lei estabelece essa restrição, pois diante de um cenário de liquidez e dispersão, o acionista tem a possibilidade de se desfazer de sua posição mediante alienação no mercado, não sendo necessário onerar a companhia.

Além de estabelecer tais restrições, a Lei das S.A. estipulou a necessidade de que o acionista comprovasse a titularidade de suas ações na data da convocação da assembleia ou do aviso de fato relevante objeto da deliberação, se anterior, para que pudesse exercer o direito. Assim dispõe o $\S 1^{\circ}$ do art. 137:

$\S 1^{\circ} \mathrm{O}$ acionista dissidente de deliberação da assembleia, inclusive o titular de ações preferenciais sem direito de voto, poderá exercer o direito de reembolso das ações de que, comprovadamente, era titular na data da primeira publicação do edital de convocação da assembleia, ou na data da comunicação do fato relevante objeto da deliberação, se anterior.

A redação original do dispositivo legal estabelecia como limite temporal para o exercício do direito de retirada a data da realização da assembleia. Porém, a Lei n ${ }^{\circ}$ 9.457, de 1997 alterou sua redação, antecipando a data limite, com o fim de evitar a chamada "indústria do recesso", caracterizada por acionistas de véspera que adquiriam ações próximo à data da assembleia com o único objetivo de exercer o direito de retirada. 
Com isso, o legislador buscou evitar “(i) a transmissão do direito de recesso, que poderia ser negociado como um ativo; e (ii) a possibilidade de se agravar o direito de recesso contra a companhia"93.

Caso não houvesse tal requisito, teríamos, de fato, uma indústria do recesso, pois os acionistas passariam a adquirir mais ações uma vez cientes de deliberação que ensejaria o direito de recesso, aumentando, assim, o ônus da companhia.

Adicionalmente, aumentar-se-ia o risco "de que o acionista especulasse com as ações, transferindo-as, a qualquer título, inclusive para fazer o preço cair, para posteriormente adquirir outras ações para exercer o recesso e com isso tornar o recesso ainda mais lucrativo para si, agravando a situação da companhia",94.

O recesso pode ser, de fato, tão oneroso à companhia que a própria Lei das S.A. estabeleceu uma espécie de direito de arrependimento à administração da companhia para que reconsidere a deliberação tomada, caso entenda que o pagamento do reembolso porá em risco a estabilidade financeira da companhia ${ }^{95}$.

Portanto, é certo que ele não pode (e não deve) ser utilizado como um mecanismo abusivo em detrimento da companhia e do interesse social a fim de que o acionista beneficie-se visando apenas ao seu interesse egoístico.

\footnotetext{
${ }^{93}$ CAMPOS, Luiz Antonio de Sampaio. Notas sobre o Direito de Recesso e a Exigência de Titularidade Ininterrupta (Art. 137, $\$ 1^{\circ}$ ). In: CASTRO, Rodrigo R. Monteiro de; WARDE JR., Walfrido Jorge; GUERREIRO, Carolina Dias Tavares (Coords.). Direito Empresarial e Outros Estudos de Direito em Homenagem ao Professor José Alexandre Tavares Guerreiro. São Paulo: Quartier Latin, 2013, p. 250.

${ }^{94}$ CAMPOS, Luiz Antonio de Sampaio. Notas sobre o Direito de Recesso e a Exigência de Titularidade Ininterrupta (Art. 137, $\S 1^{\circ}$ ). In: CASTRO, Rodrigo R. Monteiro de; WARDE JR., Walfrido Jorge; GUERREIRO, Carolina Dias Tavares (Coords.). Direito Empresarial e Outros Estudos de Direito em Homenagem ao Professor José Alexandre Tavares Guerreiro. São Paulo: Quartier Latin, 2013, p. 250.

${ }^{95}$ Lei das S.A.: Art. 137, $\S 3^{\circ}$ "Nos 10 (dez) dias subseqüentes ao término do prazo de que tratam os incisos IV e V do caput deste artigo, conforme o caso, contado da publicação da ata da assembleiageral ou da assembleia especial que ratificar a deliberação, é facultado aos órgãos da administração convocar a assembleia-geral para ratificar ou reconsiderar a deliberação, se entenderem que o pagamento do preço do reembolso das ações aos acionistas dissidentes que exerceram o direito de retirada porá em risco a estabilidade financeira da empresa".
} 


\subsection{Direito de Voto}

Conforme mencionado no início deste capítulo, o direito de voto não foi incluído no rol de direitos essenciais dos acionistas, tendo em vista a possibilidade de sua supressão, pelo estatuto social, em troca de alguma preferência ou vantagem patrimonial a ser atribuída às ações preferenciais.

$\mathrm{O}$ art. 110 da Lei das S.A. estabelece que a todas as ações ordinárias será conferido o direito de voto, correspondendo 1 (um) voto a cada ação ${ }^{96}$. É, portanto, "elemento constitutivo da ação ordinária, integrante do status socii de seu titular"97.

O direito de voto possui extrema importância, uma vez que representa direito político conferido aos acionistas por meio do qual participam para a formação de vontade da sociedade.

Por sua vez, a assembleia geral é o órgão social que reúne os acionistas, observadas as formalidades da lei, para deliberarem, por meio do direito de voto, sobre matéria de interesse da sociedade (v.g. o desenvolvimento de seus negócios, sua organização interna, etc.).

Segundo RODRIGO FERRAZ PIMENTA DA CUNHA, “a assembleia é o principal centro de formação da vontade social, constituindo eminente expressão de vontade coletiva" ${ }^{" 98}$.

Assim, o direito de voto deve ser exercido no interesse social, e não de acordo com os interesses individuais e egoísticos de cada acionista (com exceção, é claro, do exercício do direito de recesso em que o acionista dissidente prioriza o seu interesse individual a fim de retirar-se da companhia nas hipóteses previstas em lei).

\footnotetext{
${ }^{96}$ A Lei das S.A. veda expressamente o voto plural: Art. 110, § 20 "É vedado atribuir voto plural a qualquer classe de ações".

${ }^{97}$ EIZIRIK, Nelson. A Lei das S.A. Comentada. Vol. I. São Paulo: Quartier Latin, 2011, p. 620.

${ }^{98}$ CUNHA, Rodrigo Ferraz Pimenta da. O Exercício de Voto na Sociedade Anônima. In: CASTRO, Rodrigo R. Monteiro de; ARAGÃO, Leandro Santos de (Coords.). Direito Societário: Desafios Atuais. São Paulo: Quartier Latin, 2009, p. 246.
} 


\subsubsection{Interesse Social}

A definição de interesse social não é das mais fáceis, "tendo sido considerado por alguns como o problema fundamental das sociedades por ações" 99 . A esse respeito, podemos dizer que surgiram duas principais teorias buscando conceituá-lo: a teoria institucionalista e a teoria contratualista.

Basicamente, a teoria institucionalista defende que o interesse social transcende ao interesse dos acionistas, representando, portanto, um interesse superior, autônomo, distinto do interesse dos sócios ${ }^{100}$. De acordo com os que se filiam a essa teoria, a sociedade seria vista como uma instituição e o interesse social representaria um interesse próprio da sociedade como tal. Nas palavras de RODRIGO FERRAZ PIMENTA DA CUNHA, a teoria institucionalista "percebe a companhia como uma entidade autônoma, com realidade particular, distinta e superior à de seus membros" ${ }^{101}$. Assim, de certa forma, transfere ao administrador uma parcela maior de poder em detrimento dos acionistas.

Já a teoria contratualista defende a caracterização do interesse social como o interesse dos acionistas enquanto tais. Isto é, o interesse da companhia não representaria o somatório dos interesses individuais dos acionistas, tampouco um interesse autônomo desvinculado de seus sócios, mas o interesse dos acionistas considerados coletivamente (e na condição de acionistas).

Segundo ERASMo VALladÃo AZEVEDO E NovAES FranÇA, tal teoria vislumbra a sociedade "como uma relação contratual que não envolve outro interesse senão o das partes contraentes" ${ }^{102}$, representando o interesse social

\footnotetext{
${ }^{99}$ FRANÇA, Erasmo Valladão Azevedo e Novaes. Conflito de Interesses nas Assembléias de S.A. São Paulo: Malheiros, 1993, p. 21.

100 CUNHA, Rodrigo Ferraz Pimenta da. Estrutura de Interesses nas Sociedades Anônimas: Hierarquias e Conflitos. São Paulo: Quartier Latin, 2007, p. 115.

101 Ibid., p. 113.

102 FRANÇA, Erasmo Valladão Azevedo e Novaes. Conflito de Interesses nas Assembléias de S.A. São Paulo: Malheiros, 1993, p. 35 e 36.
} 
o interesse comum dos sócios, ligado à própria causa de constituição da sociedade, qual seja, o escopo do lucro.

Certo é que não há ainda um consenso com relação à melhor teoria a ser adotada. Autores como Rodrigo Ferraz Pimenta da Cunha e Lucas Coelho Larenz filiam-se à corrente institucionalista, enquanto outros como Fábio Konder Comparato, Luiz Antonio de Sampaio Campos e Nelson Eizirik filiam-se à corrente contratualista.

De fato, a corrente contratualista é a que mais se aproxima do ato de constituição da sociedade, contrato plurilateral, segundo a definição de TULLIO ASCARELLI ${ }^{103}$. Sendo a sociedade um contrato, o seu interesse deve corresponder ao interesse dos contratantes coletivamente considerados enquanto acionistas, que é a consecução do objeto social e, em última instância, a busca pelo lucro.

A criação de um interesse próprio da pessoa jurídica, autônomo, desvinculado e, em certos casos, até mesmo contrário ao interesse dos sócios não corresponde à realidade da companhia. $\mathrm{E}$ foi justamente por isso que a própria Lei das S.A. adotou a corrente contratualista ${ }^{104}$.

\subsubsection{Voto Abusivo}

Ao estabelecer, em seu art. 115, que o direito de voto deve ser exercido no interesse da companhia, a Lei das S.A. ${ }^{105}$ determina, ainda, que, caso proferido com o fim de causar dano à companhia ou a outros acionistas, ou de obter, para si ou para outrem ${ }^{106}$, vantagem a que não faz jus e de que

\footnotetext{
${ }^{103}$ ASCARELLI, Tullio. O Problema das Sociedades Anônimas e Direito Comparado. São Paulo: Saraiva \& Cia, 1945, p. 275.

${ }^{104}$ LAMY FILHO, Alfredo; PEDREIRA, José Luiz Bulhões. A Lei das S.A. Vol. II. $2^{\mathrm{a}}$ ed. Rio de Janeiro: Renovar, 1996, p. 238.

${ }^{105}$ Lei das S.A.: Art. 115. "O acionista deve exercer o direito a voto no interesse da companhia; considerar-se-á abusivo o voto exercido com o fim de causar dano à companhia ou a outros acionistas, ou de obter, para si ou para outrem, vantagem a que não faz jus e de que resulte, ou possa resultar, prejuízo para a companhia ou para outros acionistas."

106 Coíbe, com isso, a possibilidade de terceiros não acionistas se beneficiarem, utilizando interpostas pessoas (acionistas).
} 
resulte, ou possa resultar, prejuízo para a companhia ou para outros acionistas, o voto será considerado abusivo.

Ao definir o voto abusivo, a Lei das S.A. leva em conta a finalidade do voto proferido, o objetivo final do acionista ao exercer o direito de voto naquele sentido, levantando uma certa subjetividade na análise. Evidentemente, o acionista procurará não demonstrar a intenção de violação da lei ao proferir o voto, logo, a prova da intenção somente poderá basear-se em elementos circunstanciais ${ }^{107}$.

Além de inibir o voto proferido com intuito de obter vantagens indevidas, a Lei das S.A. inibiu também aquele proferido com o fim de causar dano à companhia ou a outros acionistas ${ }^{108}$. Isto é, aquele cujo objetivo seria única e exclusivamente o de provocar danos de forma intencional sem sequer beneficiar-se em contrapartida.

A enumeração das hipóteses que caracterizam o voto abusivo não é taxativa, podendo haver diversas outras situações em que se verifique a abusividade do voto ${ }^{109}$, devendo ser investigado o desvio de finalidade a que se destina o direito de voto (no caso, a proteção do interesse social).

Nos termos do $\S 3^{\circ}$ do art. 115 , o acionista deverá responder pelos danos causados pelo exercício abusivo do direito de voto, ainda que seu voto não haja prevalecido. Com isso, a Lei das S.A. deixa claro que a sanção é destinada a todos os acionistas da companhia, sejam eles majoritários ou minoritários. A preocupação central da norma é a de tutelar a persecução do interesse social por todos aqueles que façam parte da companhia.

\footnotetext{
${ }^{107}$ LAMY FILHO, Alfredo; PEDREIRA, José Luiz Bulhões. A Lei das S.A. Vol. II. $2^{\mathrm{a}}$ ed. Rio de Janeiro: Renovar, 1996, p. 242.

${ }^{108}$ FRANÇA, Erasmo Valladão Azevedo e Novaes. Conflito de Interesses nas Assembléias de S.A. São Paulo: Malheiros, 1993, p. 83.

${ }^{109}$ Nesse sentido, EIZIRIK, Nelson. A Lei das S.A. Comentada. São Paulo: Quartier Latin, 2011, p. 654; MARTINS, Fran. Comentários à Lei das Sociedades Anônimas. $4^{\mathrm{a}}$ ed. Rio de Janeiro: Forense, 2010, p. 396; e REGO, Marcelo Lamy. Direitos dos Acionistas. In: LAMY FILHO, Alfredo; PEDREIRA, José Luiz Bulhões (Coords.). Direito das Companhias. Vol. I. Rio de Janeiro: Forense, 2009, p. 416.
} 
Nesse sentido, FRAN MARTINS:

"De tudo se conclui que, com a introdução da regra do art. 115 em nosso direito, visou a lei dar o verdadeiro significado do voto nas assembleias da sociedade, estabelecendo normas aplicáveis a todos os acionistas, sejam eles majoritários ou minoritários. Naturalmente, os acionistas minoritários se beneficiarão dessa norma visto como, pela lei da maioria, teriam eles que se submeter ao decidido pela sociedade ainda mesmo que a deliberação fosse tomada como abuso de voto por parte da maioria",110.

A redação do dispositivo suscita algumas dúvidas com relação à possibilidade de anulação do voto proferido em desacordo com o interesse social. Isso porque, ao tratar de conflito de interesse (hipótese diversa do voto abusivo), a Lei das S.A. expressamente determina que "a deliberação tomada em decorrência do voto de acionista que tem interesse conflitante com o da companhia é anulável".

Por outro lado, ao tratar do voto abusivo, a Lei das S.A. estipula apenas que o acionista responderá pelo exercício abusivo do direito de voto, sem mencionar a possibilidade de anulação.

Impor à companhia o ônus de conviver com uma deliberação tomada por meio de voto abusivo seria uma insensatez. Assim, o que se entende é que "nesse caso, a possibilidade de anulação da deliberação assemblear ocorre por vício intrínseco, ou seja, por defeito na formação do negócio jurídico em si" ${ }^{\prime 11}$.

\section{Na lição de AlFRedo LAMY FILHO e JosÉ LUIZ BUlHÕES PEDREIRA: \\ "O acionista que profere voto com outro fim que não o interesse da companhia pratica ato ilícito - viola o disposto no artigo 115 da Lei no 6.404/76. Seu voto é}

\footnotetext{
${ }^{110}$ MARTINS, Fran. Comentários à Lei das Sociedades Anônimas. $4^{\mathrm{a}}$ ed. Rio de Janeiro: Forense, 2010, p. 396.

${ }^{111}$ CUNHA, Rodrigo Ferraz Pimenta da. O Exercício de Voto na Sociedade Anônima. In: CASTRO, Rodrigo R. Monteiro de; ARAGÃO, Leandro Santos de (Coords.). Direito Societário: Desafios Atuais. São Paulo: Quartier Latin, 2009, p. 259.
} 
anulável, e se os votos que determinaram a deliberação são ilícitos, a própria deliberação é ilícita e, portanto, anulável ",112.

Conclui-se, portanto, que ainda que não previsto expressamente pela lei a possibilidade de anular o voto abusivo, não restam dúvidas de que tal pretensão é legítima, visto que constitui ato ilícito e, portanto, passível de anulação.

Tendo sido feitas essas breves considerações com relação aos principais direitos políticos e patrimoniais dos acionistas, faz-se necessário analisar como eles estão relacionados quando as ações são dadas em mútuo. Tal questão bem como suas repercussões jurídicas serão examinados com atenção no próximo capítulo.

${ }^{112}$ LAMY FILHO, Alfredo; PEDREIRA, José Luiz Bulhões. A Lei das S.A. Vol. II. $2^{\mathrm{a}}$ ed. Rio de Janeiro: Renovar, 1996, p. 241, destacou-se. No mesmo sentido, "A invalidade do voto pode decorrer ainda de ter sido ele proferido (...) (b) abusivamente. (...) os vícios do voto, se decisivos para a formação da maioria, podem levar à anulação da assembleia, ou de uma ou algumas de suas deliberações, conforme o caso". FRANÇA, Erasmo Valladão Azevedo e Novaes. Invalidade das Deliberações de Assembléia das S.A. São Paulo: Malheiros, 1999, p. 117. 


\section{Capítulo III \\ Principais Direitos Políticos e Patrimoniais dos Acionistas no Mútuo de Ações}

Conforme demonstrado no Capítulo I deste trabalho, a operação conhecida no jargão de mercado como aluguel de ações trata-se na verdade de um mútuo.

Tratando-se de um mútuo, o empréstimo de ações transfere a propriedade do bem fungível - as ações - àquele que o toma emprestado. Com isso, o mutuário passa a poder não apenas usar, como também dispor livremente das ações alcançando, assim, a finalidade da operação. Poderá, portanto, alienar as ações como se seu dono fosse.

Como consequência da transferência de domínio, o mutuário da operação passa a ser, ainda que de forma temporária, o novo acionista da companhia, o que acarreta uma mudança no titular dos direitos políticos e patrimoniais inerentes à propriedade daquelas ações.

Serão analisados, um a um, os direitos políticos e patrimoniais no mútuo de ações e quais as repercussões jurídicas que a transferência desses direitos pode gerar.

\subsection{Direito de Participar nos Lucros}

Em tese, com a transferência da propriedade das ações, e, com isso do direito de usar, dispor e fruir da coisa, o direito de participar nos lucros (traduzido concretamente para o direito ao recebimento de dividendos com a sua declaração pela companhia) passa a ser do novo acionista, ou seja, do tomador.

Isso porque, como vimos, os dividendos serão devidos e pagos àquele que for titular ou usufrutuário da ação na data da declaração em assembleia geral. Portanto, caso titular das ações quando da deliberação assemblear que declara os dividendos, o mutuário da ação passa a deles ter direito. 
Ocorre que, reconhecendo tal efeito, a Instrução CVM n 441 determinou em seu art. 10 que "as entidades prestadores desse serviço [de empréstimo de ações] são responsáveis, perante os titulares dos valores mobiliários emprestados, pela sua reposicão e a dos eventuais direitos a estes atribuídos no período de empréstimo".

Por sua vez, a própria BM\&FBOVESPA estabeleceu nos seus Procedimentos Operacionais que os dividendos deverão ser reembolsados pelo tomador ao doador. Isto é, a BM\&FBOVESPA irá provisionar em favor do mutuante um crédito no valor dos dividendos declarados pela companhia emissora proporcionalmente à quantidade de ações que estão dadas em mútuo. Tal crédito é provisionado na data de declaração dos dividendos.

Em contrapartida, o mutuário fica encarregado de manter, como forma de garantia, o mesmo montante a ser creditado ao mutuante até a data do efetivo pagamento pela companhia.

Assim, no dia do pagamento dos dividendos aos acionistas da companhia emissora, feito por meio da instituição custodiante, será debitado da conta do mutuário - que é quem figura como acionista e efetivamente recebe os proventos, caso seja titular das ações no momento da declaração e creditado na conta do mutuante o valor correspondente aos dividendos a que faz jus.

Nota-se, portanto, que o direito ao recebimento de dividendos, como um direito de crédito que o acionista tem contra a companhia, pode ser objeto de cessão e é justamente o que ocorre na operação de mútuo de ações como regra, por força das normas regulamentares das operações em bolsa. O tomador, formalmente titular do direito a receber dividendos, transfere por força contratual o seu direito de receber dividendos ao doador.

\section{2. $\quad$ Direito de Preferência na Subscrição de Ações}


O direito de preferência legal é também um direito conferido ao titular da ação. Assim, com a transferência das ações por meio da operação de mútuo de ações, o titular do direito passa a ser o mutuário.

Ocorre que, da mesma forma que o direito de receber dividendos, o direito de opção para subscrição de ações é passível de negociação entre as partes. Assim, a BM\&FBOVESPA permite, mas não obriga, que o mutuário faça uma promessa de cessão do direito ao mutuante.

Caso o mutuário não transfira o direito, a BM\&FBOVESPA garante ao mutuante "subscrever" as ações que tem direito via BTC, a fim de assegurar a manutenção proporcional de sua participação na companhia. Isto é, desde que manifeste o seu interesse dentro do cronograma estabelecido pela companhia emissora, será debitado da conta do mutuante o valor referente ao pagamento da subscrição e creditado na conta do tomador para que este vá ao mercado adquirir as novas ações. A diferença entre o preço de mercado das ações e o preço de subscrição das ações será arcada inteiramente pelo tomador.

Com isso, a BM\&FBOVESPA pretendeu evitar que o mutuante fosse diluído por conta da operação de empréstimo de ações. Isto é, a fim de manter o estímulo às partes doadoras em realizar operações de mútuo de ações, a BM\&FBOVESPA estabeleceu mecanismos para garantir que, independentemente de perder de forma temporária a propriedade das ações, o mutuante possa manter alguns direitos inerentes à titularidade da ação: tais como o direito de preferência legal (e o direito ao recebimento de dividendos, como se expôs acima).

Conclui-se, portanto, acerca da possibilidade de cessão ou promessa de cessão dos direitos patrimoniais acima mencionados, tendo em vista que deles decorrem direitos de crédito que, obviamente, podem ser cedidos. Nesse sentido, confira-se a lição de Alfredo LAMY FilHo e JosÉ LuIZ BULHÕES PEDREIRA: 
"Cabe destacar, ainda, que os direitos de participação nos lucros sociais e no acervo líquido, assim como o de preferência na subscrição de valores mobiliários, têm por objeto quota-parte ideal de um todo e dão origem ao nascimento (pela ocorrência de determinados atos) de direitos de crédito com prestações determinadas, que podem ser cedidos" $" 113$.

\subsection{Direito de Recesso}

A questão da legitimidade para exercer o direito de retirada no mútuo de ações foi bastante discutida e alvo de controvérsias recentemente.

Em maio de 2011, as companhias do Grupo Oi divulgaram fato relevante anunciando a realização de operações para implementar sua reorganização societária que ensejariam o direito de recesso.

Ao tratarem do direito de retirada no fato relevante, conferiram legitimidade para exercê-lo apenas àqueles acionistas que mantivessem a titularidade ininterrupta das ações desde a data da divulgação do fato relevante até a data do exercício efetivo do direito.

A partir daí, surgiu uma série de questionamentos por parte dos investidores que pretendiam negociar com suas ações naquele período, inclusive realizar empréstimos via sistema BTC, a respeito da legitimidade para exercer o direito de recesso, bem como da necessidade de titularidade ininterrupta das ações para tanto.

Partindo deste caso como exemplo ilustrativo, passaremos a analisar a questão.

\subsubsection{Necessidade de Titularidade Ininterrupta}

Conforme exposto no Capítulo II, o $§ 1^{\circ}$ do art. 137 da Lei das S.A. foi alterado pela Lei $\mathrm{n}^{\circ}$ 9.457, de 1997 para antecipar a data limite de verificação dos legitimados para exercer o direito de retirada - deixando de

\footnotetext{
${ }^{113}$ PEDREIRA, José Luiz Bulhões; LAMY FILHO, Alfredo. Ação Como Participação Societária. In: LAMY FILHO, Alfredo; PEDREIRA, José Luiz Bulhões (Coords.). Direito das Companhias. Vol. I. Rio de Janeiro: Forense, 2009, p.221.
} 
ser a data de realização da assembleia para passar a ser a data da publicação de sua convocação ou da divulgação de fato relevante objeto da operação justamente com o fim de eliminar a chamada "indústria do recesso".

A finalidade da norma com essa alteração foi, portanto, evitar que acionistas adquirissem ações às vésperas da assembleia com o único objetivo de beneficiar-se economicamente com o exercício do direito de recesso e, em contrapartida, aumentassem o ônus da companhia.

Como já mencionado, apesar de enquadrado na categoria de direito essencial do acionista, o direito de retirada é também excepcional, visto que permite ao acionista sobrepor seu interesse individual ao interesse social, onerando a companhia por meio do pagamento do reembolso ao invés de desfazer-se de sua posição mediante alienação privada ou em bolsa.

O direito de recesso não pode ser visto como oportunidade de negócio e foi justamente por isso que a Lei das S.A. estabeleceu alguns requisitos para o seu exercício e a titularidade ininterrupta é, definitivamente, um deles.

Se o acionista encontra outro caminho satisfatório para retirar-se da companhia por meio da alienação de suas ações no mercado, durante o período compreendido entre a data da ciência da deliberação e o do exercício efetivo do direito de recesso, não cabe mais a ele a prerrogativa de receber o valor de reembolso.

Isso porque ao fazê-lo o acionista deixa claro que as ações daquela companhia possuem liquidez e dispersão suficientes para que ele possa retirar-se da companhia por outra via.

Nesse sentido, o voto proferido pela Diretora Luciana Dias no âmbito do Processo Administrativo CVM no RJ2012/0249, uma das reclamações do caso Oi:

"Orequisito de propriedade ininterrupta, embora não expresso, decorre da lógica

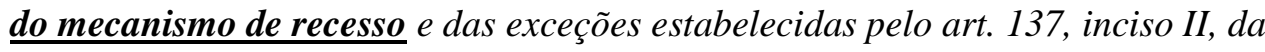


Lei 6.404, de 1976. Alienar as acões é praticar um ato contrário à expectativa de exercício do recesso, é deixar de ser acionista ${ }^{114}$.

Assim, uma vez ciente de deliberação que possa ensejar o exercício do direito de recesso, por meio da convocação da assembleia ou da divulgação do aviso de fato relevante, o acionista que decidir negociar com suas ações estará renunciando ao direito de exercer o recesso ${ }^{115}$.

Não se trata, de forma alguma, de violação ao princípio da livre circulação das ações. Desejando alienar suas ações, o acionista poderá livremente fazê-lo como alternativa para o desinvestimento. No entanto, para fins de exercício do direito de recesso, deverá mantê-las em carteira até a data do efetivo exercício.

Pretendeu-se comparar a situação do acionista que detém suas ações no momento da ciência da deliberação que enseja o recesso mas as aliena posteriormente, com a do acionista que detém suas ações no momento em que o dividendo é declarado mas as aliena posteriormente, antes do pagamento.

Trata-se, no entanto, de situações completamente distintas. A intenção do art. 205 da Lei das S.A. foi a de separar o direito de crédito referente ao pagamento do dividendo da própria ação, a fim de que ela pudesse ser negociada como um bem fungível. Ou seja, simplesmente para que não houvesse distinção entre ações com direito a dividendo e ações sem direito a dividendo circulando no mercado ${ }^{116}$.

\footnotetext{
${ }^{114}$ Julgado em 16.02.2012.

${ }^{115}$ Electa una via, non datur recursos ad alteram.

${ }^{116}$ CAMPOS, Luiz Antonio de Sampaio. Notas sobre o Direito de Recesso e a Exigência de Titularidade Ininterrupta (Art. 137, $\S 1^{\circ}$ ). In: CASTRO, Rodrigo R. Monteiro de; WARDE JR., Walfrido Jorge; GUERREIRO, Carolina Dias Tavares (Coords.). Direito Empresarial e Outros Estudos de Direito em Homenagem ao Professor José Alexandre Tavares Guerreiro. São Paulo: Quartier Latin, 2013, p. 251.
} 
Com relação ao recesso, a alienação das ações, por meio da venda em bolsa, já satisfaz o objetivo do exercício do direito de retirada - o acionista logrou, por outra via, retirar-se da companhia, repondo o valor de suas ações.

LUIZ ANTONIO DE SAMPAIO CAMPOS faz a diferenciação:

“Já no recesso, a situação é de todo diversa e o regime mais específico. Não só se pretendeu impedir a negociação do direito de recesso (mas, não da própria ação), mas também a negociação em função do recesso ou por causa do recesso, e por isso se restringiu àquele acionista e àquelas ações. Inclusive porque, diferentemente do dividendo, o recesso, para ser exercido, exige a titularidade da ação, diferentemente do dividendo que uma vez declarado se descola da

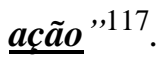

Da mesma forma, a exigência de titularidade ininterrupta se aplica ao mútuo e nele produz os mesmos efeitos. Isto é, na hipótese de o acionista ter dado em mútuo suas ações após a divulgação do fato relevante ou da publicação da convocação da assembleia, perderá a titularidade das ações tendo em vista que o mútuo transfere a propriedade das ações - e, portanto, decairá do direito de exercer o recesso.

Assim, ao transferir a propriedade das ações por meio do mútuo, optou por renunciar ao exercício do direito de recesso e receber um juros, em contrapartida.

Nesse caso, tampouco o mutuário terá direito de exercê-lo, uma vez que lhe faltaria legitimidade para tanto, visto que não era titular das ações no momento da divulgação da operação.

Com relação aos contratos de empréstimo em aberto na data do fato relevante ou da convocação da assembleia, terá legitimidade para exercê-lo o mutuário (novo proprietário da ação) - e não o mutuante - desde que

${ }^{117}$ Idem, destacou-se. 
detenha sua posição de titular das ações até a data do exercício efetivo do direito.

Foi, inclusive, nesse sentido que as reclamações do Caso Oi foram julgadas. Confira-se:

"Assim, pelo exposto, reconheço que os contratos de empréstimo ou de aluguel de ações transferem a propriedade do bem e, em consequência, ações emprestadas não são ininterruptamente mantidas pelos mutuantes. Daí porque julgo improcedente o presente recurso" ${ }^{\text {118. }}$.

Tal decisão deixou alguns investidores doadores descrentes com relação à operação de empréstimo de ações, uma vez que ficaram impossibilitados de exercer o direito de recesso sem ter recebido o preço pela alienação das ações, mas apenas juros.

E, ainda que houvessem contratado na modalidade callable, as ações apenas voltariam para sua propriedade no prazo de 4 (quatro) dias, o que não os legitimaria a tempo para exercer o direito de recesso.

Um dos argumentos dos investidores dizia respeito à possibilidade de o tomador transferir ao doador o direito de recesso ou o seu exercício via BTC - como ocorre no direito de preferência legal.

No entanto, tal analogia não merece prosperar. A possibilidade de transferência do direito de preferência legal está expressamente prevista nas regras da BM\&FBOVESPA, sendo, portanto, um arranjo contratual. Ademais, trata-se de um direito patrimonial que pode ser objeto de promessa de cessão ${ }^{119}$.

Como na operação de mútuo de ações o mutuante fica exposto economicamente à companhia, já que ações equivalentes voltarão à sua

\footnotetext{
${ }^{118}$ Processo Administrativo CVM no SP2011/0304, Rel. Dir. Otavio Yazbek, j. em 16.02.2012.

${ }^{119}$ Como exposto anteriormente, o direito de preferência só pode ser efetivamente cedido com a deliberação de aumento de capital. Antes disso, há uma promessa de cessão. É o que ocorre no momento da celebração do contrato de mútuo de ações.
} 
propriedade ao final do contrato, faz sentido que os direitos econômicos the sejam transferidos - o que não ocorre com os direitos políticos, pois personalíssimos e impassíveis de cessão.

Note-se que a situação em tela do caso Oi é, na verdade, excepcional e não afeta, como pretenderam argumentar os investidores, o mercado de mútuo de ações.

Em regra, esse mercado é mais desenvolvido no caso de ações com alto índice de liquidez, uma vez que o mutuário precisa contar com a liquidez dos ativos para que possa recomprá-los e devolvê-los ao mutuante no final do contrato.

Portanto, diante de um mercado ativo de empréstimo de ações com alto grau de liquidez não há sequer direito de recesso, caso se verifique também a observância do critério de dispersão.

No caso concreto, não faltava o requisito da liquidez nas ações do Grupo Oi, mas havia uma falta teórica de dispersão acionária, o que ensejou a possibilidade de exercício do direito de recesso.

\subsection{Direito de Voto}

Outra questão extremamente relevante diz respeito à titularidade do direito de voto na vigência do contrato de mútuo de ações.

Com a transferência da propriedade das ações por meio do mútuo, o direito de voto passa a ser do novo titular das ações, isto é, do mutuário, pois, como se sabe, "o direito de voto conferido pela ação cabe, em princípio, ao proprietário desta" ${ }^{20}$.

Assim, perde o mutuante, durante a vigência do contrato de empréstimo, o direito de votar nas deliberações assembleares ocorridas neste período. Isso porque, conforme mencionado no Capítulo II, a Lei das S.A.

${ }^{120}$ REGO, Marcelo Lamy. Direitos dos Acionistas. In: LAMY FILHO, Alfredo; PEDREIRA, José Luiz Bulhões (Coords.). Direito das Companhias. Vol. I. Rio de Janeiro: Forense, 2009, p. 
veda expressamente o voto plural em seu art. $110, \S 2^{\circ}$ e, de forma alguma, poderia o mutuante exercer o direito em concomitância com o mutuário.

A respeito da atribuição do direito de voto ao mutuário, já se manifestou a área técnica da CVM por meio do MEMO/CVM/SEP/GEA$4 / \mathrm{N}^{\circ} 099 / 06^{121}$ :

"Na medida em que as ações sob aluguel conservam seus atributos originais, o tomador, durante a vigência do contrato, detém a condição de sócio da Companhia, podendo exercer direito de voto que a elas for inerente".

No mesmo sentido, FERNANDA KEHDI SCHAHIN:

“(...) enquanto o contrato estiver em vigor, o doador do empréstimo perde os direitos políticos intrínsecos à titularidade de uma ação. As prerrogativas de votar e participar de assembleias somente são permitidas ao titular da ação, no caso o tomador do empréstimo ou o terceiro a quem a ação tenha sido posteriormente alienada, de modo a evitar que uma determinada ação proporcione mais de um voto", ${ }^{\prime 22}$.

Poder-se-ia argumentar sobre a possibilidade de o direito de voto ser dissociado da titularidade da ação. No entanto, quando a Lei das S.A. quis excepcionar a regra geral de que o titular do direito de voto é o proprietário da ação, ela o fez expressamente.

A exemplo disso, o art. 114 da Lei das S.A. prevê que o direito de voto da ação gravada com usufruto, se não regulado no ato de constituição do gravame, só poderá ser exercido mediante prévio acordo entre o nu proprietário e o usufrutuário. Permite expressamente, portanto, que, por arranjo contratual, o direito de voto seja exercido por outro que não o titular da ação: o usufrutuário.

\footnotetext{
${ }^{121}$ Datado de 23.10.2006.

122 SCHAHIN, Fernanda Kehdi. Vendas a Descoberto no âmbito do Empréstimo de Ações: estudo do modelo regulatório brasileiro. In: Revista de Direito Bancário e do Mercado de Capitais. São Paulo: Malheiros, n. 49, ano 13, p. 57, jul/set, 2010.
} 
No caso das ações empenhadas, ainda que não haja dissociação entre o direito de voto e a titularidade da ação, a Lei das S.A. permite que o contrato disponha sobre a necessidade do consentimento do credor pignoratício no sentido do voto de certas deliberações.

Da mesma forma, na alienação fiduciária cabe ao devedor o exercício do voto, porém desde que dentro dos limites do contrato.

Essas exceções, no entanto, são previstas expressamente pela lei. Dessa forma, ao empréstimo de ações aplica-se a regra geral de que o direito de voto cabe ao titular da ação, logo, ao tomador do empréstimo.

Não seria possível, como ocorrem nos direitos patrimoniais, a cessão do direito de voto ao doador. O direito de voto não é passível de cessão, visto que está fundamentado em três princípios: (i) é conferido ao acionista para que o exerça na assembleia geral a fim de contribuir com a formação da vontade coletiva; (ii) é incindível da ação e somente pode ser exercido pelo acionista (com exceção do usufruto); e (iii) a decisão sobre o conteúdo do voto é privativo do acionista e não pode ser transferida a terceiro ${ }^{123}$.

Nas palavras de TRAJANO DE MIRANDA VALVERDE:

"Em toda corporação, com efeito, o direito de voto só se compreende exercido por quem possui a qualidade de membro. Só a lei teria a licença de autorizar a cessão do exercício do direito de voto. Mas a própria lei sancionaria um absurdo, se permitisse a transferência do direito de voto, alienação irrestrita de um direito, que ela mesma faz depender da aquisição de uma qualidade, a de membro da sociedade. Como explicar, lógica e juridicamente, a aquisição desse direito sem a prévia ou simultânea aquisição da qualidade de membro ou sócio?",124

Tampouco poder-se-ia gravar as ações objeto de empréstimo com usufruto a fim de reservar o direito de voto ao mutuante, uma vez que para

\footnotetext{
${ }^{123}$ LAMY FILHO, Alfredo; PEDREIRA, José Luiz Bulhões. A Lei das S.A. Vol. II. $2^{\text {a }}$ ed. Rio de Janeiro: Renovar, 1996, p. 291.

${ }^{124}$ VALVERDE, Trajano de Miranda. Sociedades por Ações (Comentários ao Decreto-Lei n 2.627 de 26 de setembro de 1940). Vol. II. $2^{\text {a }}$ ed. Rio de Janeiro: Forense, 1953, p. 58.
} 
que possam ser mutuadas, as ações devem apresentar-se como bens fungíveis. Justamente por isso que o $§ 4^{\circ}$ do art. $2^{\circ}$ da Instrução CVM n 441 determinou que "somente serão admitidas operações de empréstimo que tenham por objeto valores mobiliários depositados em custódia nas entidades mencionadas no caput deste artigo, livres de ônus ou gravames que impecam sua circulacão".

Ultrapassada a questão da legitimidade para exercer o direito de voto, é importante analisar as consequências e efeitos jurídicos que o exercício do voto pelo mutuário podem trazer.

Isso porque relacionado à perquirição do interesse social, a Lei das S.A. previu uma correspondência entre o direito de voto e o investimento na sociedade.

O acionista busca exercer seu voto no interesse da companhia justamente porque nela possui interesse econômico e, com isso, procura tomar decisões que entende serem as mais acertadas para a saúde financeira dela. Há, de fato, um interesse positivo no rendimento da companhia ${ }^{125}$.

Ocorre que, no caso do empréstimo de ações, há uma total desvinculação entre o direito de voto e o investimento na sociedade, uma vez que o tomador mantém-se na qualidade de acionista por prazo determinado e não paga o preço das ações. Ademais, por força da regra regulamentar do BTC, transfere o direito ao recebimento de dividendos ao mutuante.

Nesse sentido, GABRIEL LEUTEWILER et al:

"Se é possivel afirmar que nas operações de empréstimos de ações o voto segue como indissociável da ação, também podemos afirmar que nelas não se mantém a relação de proporcionalidade entre poder político e poder econômico na sociedade. (...) Efetivamente, não há no empréstimo de ações o interesse residual

\footnotetext{
${ }^{125}$ LEUTEWILER, Gabriel; COMIRAN, Giovana Cunha; HAENSEL, Taimi. Aluguel de Ações: Panorama do negócio jurídico, problemas do direito estrangeiro e a eficiência do modelo brasileiro e a questão do voto no direito brasileiro. In: Revista de Direito Mercantil, Industrial, Econômico e Financeiro. São Paulo: Malheiros, n. 161/162, p. 183, jan/ago, 2012
} 
característico do acionista. Além disso, o preco que o tomador paga pelo empréstimo é significativamente menor do que aquele que se pagaria pela compra da aç̃̃o "126.

O mutuário não possui qualquer interesse econômico na companhia e, sem dúvidas, o interesse econômico representa grande incentivo para que o acionista profira seu voto no melhor interesse da companhia ${ }^{127}$.

A desproporcionalidade entre o direito de voto e o interesse econômico é denominada pela doutrina estrangeira de HENRY T. C. Hu e BERNARD BLACK de "empty voting" 128 . De acordo com HU e BLACK, o voto do tomador seria vazio, visto que seu risco tenderia a zero por não participar das perdas econômicas decorrentes das deliberações sociais.

Assim, operações de grande importância para a companhia, tais como as de cancelamento de registro (para fechamento de capital), poderiam acabar sendo decididas por acionistas que não possuem qualquer interesse a longo prazo na companhia.

Poder-se-ia, inclusive, imaginar uma situação em que o voto proferido pelo mutuário fosse de encontro ao interesse social, de modo a intencionalmente prejudicar os negócios da companhia.

\footnotetext{
Assim, destacam Henry T. C. Hu e Bernard Black:

"In an extreme case, an investor can vote despite having negative economic ownership, which gives the investor an incentive to vote in ways that reduce the company's share price", ${ }^{29}$.
}

\footnotetext{
${ }^{126}$ LEUTEWILER, Gabriel; COMIRAN, Giovana Cunha; HAENSEL, Taimi. Aluguel de Ações: Panorama do negócio jurídico, problemas do direito estrangeiro e a eficiência do modelo brasileiro e a questão do voto no direito brasileiro. In: Revista de Direito Mercantil, Industrial, Econômico e Financeiro. São Paulo: Malheiros, n. 161/162, p. 183, jan/ago, 2012, destacou-se.

${ }^{127}$ HU, Henry T. C.; BLACK, Bernard. The Vote Buying: Empty Voting and Hidden (Morphable) Ownership. In: Southern California Law Review, Vol. 79, 2006, p. 811. Disponível em <http://papers.ssrn.com/sol3/papers.cfm?abstract_id=904004>. Acesso em 01/04/2014. ${ }^{128}$ Idem.

129 Tradução literal: Imaginando-se uma situação extrema, um investidor, com interesse econômico negativo na companhia, poderia, inclusive, votar nas deliberações sociais de forma a reduzir o preço da ação da companhia. Ibidem, p. 815.
} 
Com isso, poderiam lucrar no curto prazo, mediante a seguinte estratégia: tomariam as ações em empréstimo a fim de evitar a aprovação de uma operação, logo após, aproveitando-se da informação de que a operação seria rejeitada, as venderiam ainda em alta no mercado e, em um segundo momento, com a queda da cotação das ações, as recomprariam a preço muito inferior para devolver ao mutuante ${ }^{130}$.

Foi justamente o que ocorreu em Hong Kong no caso Henderson Land v. Henderson Investment, destacado por HU e BLACK ${ }^{131}$, no qual diante do anúncio de que a Henderson Land iria realizar uma oferta pública de cancelamento de registro a fim de adquirir as ações remanescentes da sua subsidiária Henderson Investment, determinados fundos de investimento tomaram em empréstimo, dias antes da realização da assembleia, ações de emissão da companhia com o intuito de rejeitar a operação e implementar a estratégia acima destacada.

Como, segundo a legislação de Hong Kong, a operação podia ser impedida por acionistas titulares de $10 \%$ das ações em circulação (que equivalia, no caso, à 2,5\% do total de ações), os fundos obtiveram total êxito em sua estratégia e rejeitaram a proposta de cancelamento de registro da Henderson Investment, o que fez com que a cotação das ações - que estava em alta com a expectativa do mercado de aprovação da operação despencasse.

A respeito de situações como essas, duas questões devem ser levadas em consideração: (i) o mutuário, enquanto acionista - ainda que temporário - da companhia, está sujeito às sanções impostas no caso de voto abusivo; e

\footnotetext{
${ }^{130}$ LEUTEWILER, Gabriel; COMIRAN, Giovana Cunha; HAENSEL, Taimi. Aluguel de Ações: Panorama do negócio jurídico, problemas do direito estrangeiro e a eficiência do modelo brasileiro e a questão do voto no direito brasileiro. In: Revista de Direito Mercantil, Industrial, Econômico e Financeiro. São Paulo: Malheiros, n. 161/162, p. 186, jan/ago, 2012.

${ }^{131}$ HU, Henry T. C.; BLACK, Bernard. The Vote Buying: Empty Voting and Hidden (Morphable) Ownership. In: Southern California Law Review, Vol. 79, 2006, p. 835. Disponível em <http://papers.ssrn.com/sol3/papers.cfm?abstract_id=904004>. Acesso em 01/04/2014.
} 
(ii) a BM\&FBOVESPA impõe limites de concentração por investidor no mútuo de ações.

Assim, caso profira seu voto de forma ilegítima, isto é, contra o interesse social e, portanto, influenciado por um interesse econômico negativo na companhia (como ocorreu no caso Henderson Land v. Henderson Investment), o mutuário responderá pelos danos causados pelo exercício abusivo de seu direito de voto. E, se seu voto houver prevalecido, estará sujeito à anulação e, consequentemente, será anulada a deliberação viciada.

Essa análise deverá ser feita a posteriori, uma vez que não seria viável o seu controle a priori. Primeiramente, porque não haveria como controlar ou ter ciência das operações de empréstimo de ações realizadas pelos acionistas de determinada companhia, uma vez que ocorrem via sistema BTC e as partes são mantidas anônimas.

Em segundo lugar, porque não seria possível determinar de pronto se o voto proferido pelo mutuário se daria, necessariamente, no sentido contrário do interesse da companhia. Seria plenamente legítima a situação em que um acionista tomasse ações emprestado via sistema BTC a fim de garantir a aprovação de uma deliberação social tomada no interesse da companhia.

Houve quem ${ }^{132}$ dissesse que poderia ser uma forma disfarçada e, portanto, sem obedecer aos requisitos legais ${ }^{133}$ e regulamentares ${ }^{134}$, de realizar um pedido público de procuração (o chamado "proxy"), cujo objetivo é garantir, com a concordância dos acionistas outorgantes, o quórum

\footnotetext{
${ }^{132}$ Argumento utilizado por Polo Norte Fundo De Investimento Multimercado, através de seu administrador e representante legal, Mellon Serviços Financeiros DTVM S.A., e por Brandes Investment Partners L.P., no âmbito do Processo Administrativo CVM no RJ2006/7840, a fim de requerer a interrupção do curso do prazo de antecedência de convocação de AGE.

${ }^{133} \mathrm{O} \S 2^{\circ}$ do art. 126 da Lei das S.A. estabelece como requisitos que o pedido: a) contenha todos os elementos informativos necessários ao exercício do voto pedido; b) faculte ao acionista o exercício de voto contrário à decisão com indicação de outro procurador para o exercício desse voto; c) seja dirigido a todos os titulares de ações cujos endereços constem da companhia ${ }^{134}$ Previstos nos arts. 22 e ss da Instrução CVM nº 481/2009.
} 
necessário para a instalação de assembleia e aprovação de determinada matéria.

No entanto, no proxy, o acionista outorga uma procuração para que o procurador (geralmente, outro acionista ou administrador) vote por ele de acordo com a sua orientação. Trata-se, portanto, de voto proferido em nome de terceiro.

Já no mútuo de ações, o acionista toma ações em empréstimo, a fim de garantir a aprovação de determinada deliberação. Nesse caso, o voto seria proferido em nome próprio - não em nome de terceiro -, uma vez que o mútuo de ações transfere a propriedade das ações do mutuante para o mutuário.

Ainda que a mesma quantidade de ações equivalentes seja entregue ao mutuante ao final do contrato e, com isso ele acabe participando dos efeitos daquela deliberação na qual não proferiu voto, é importante destacar que o próprio mutuante, ciente da realização de assembleia, autorizou o mútuo e manteve disponíveis suas ações no sistema BTC.

Assim, tendo sido tomada no interesse da companhia, o mutuante não teria como reclamar que estaria submetido à deliberação da qual não participou ou não participou com a integralidade de ações que detinha inicialmente.

Além disso, como exposto no Capítulo I, é permitido que o mutuante firme o contrato de mútuo de ações na modalidade callable, na qual o mutuário obriga-se a restituir a mesma quantidade de ações de mesma classe e espécie no prazo de D+4 contados do pedido. Portanto, em último caso, poderia solicitar a restituição das ações a fim de votar nas deliberações assembleares.

Outro remédio que deve ser destacado para evitar tais situações seria o limite de concentração imposto pela BM\&FBOVESPA. Segundo os 
Procedimentos Operacionais divulgados pela BM\&FBOVESPA, devem ser obedecidos os seguintes limites de concentração: (i) limite de mercado de $20 \%$ (vinte por cento) do total de ações em circulação de determinada companhia; (ii) limite por investidor de 3\% (três por cento) das ações em circulação de emissão de determinada companhia; e (iii) limite por intermediário de 6,5\% (seis e meio por cento) das ações em circulação de emissão de determinada companhia.

A imposição destes limites dificulta substancialmente a possibilidade de que mutuários aumentem significativamente a sua participação com a única e exclusiva finalidade de prevalecer nas deliberações assembleares.

Além dos remédios previstos pela legislação e pelas normas das entidades autorreguladoras, há que se considerar que, em regra, o mutuário toma ações em empréstimo para vender as ações ou cobrir posições descobertas e não para retê-las a fim de votar em assembleias.

Tendo sido expostas as questões referentes ao exercício de determinados direitos políticos e patrimoniais na vigência de operação de mútuo de ações, será analisada, no próximo capítulo, a possibilidade de realização da referida operação durante os períodos de vedação à negociação estabelecidos por norma regulamentar.

Para tanto, serão analisados, primeiramente, os principais contornos da prática de insider trading, para, em seguida, verificar-se a intenção da norma regulamentar que proíbe a negociação em determinados períodos e, com isso, chegar-se a uma conclusão com relação à sua aplicação na operação de mútuo de ações. 


\section{Capítulo IV \\ Períodos de Vedação à Negociação \\ e o Mútuo de Ações}

\subsection{A Proibição da Prática de Insider Trading}

$\mathrm{O}$ art. 155 da Lei das S.A. veda a utilização indevida de informação privilegiada (insider trading) por administradores de companhia aberta. A conduta está tipificada no $\S 1^{\circ}$ do dispositivo, que veda a conduta do administrador destinada a "valer-se de informação" "que ainda não tenha sido divulgada para conhecimento do mercado" "para obter, para si ou para outrem, vantagem mediante compra ou venda de valores mobiliários".

A lei pressupõe, portanto, a presença concomitante de quatro requisitos para caracterizar a prática de insider trading, quais sejam: (i) existência de uma informação relevante ainda não divulgada ao mercado; (ii) acesso privilegiado do agente a essa informação; (iii) efetiva utilização da informação em negociação no mercado de valores mobiliários; e (iv) finalidade do agente de, ao utilizar a informação, auferir vantagem para si ou para outrem.

JoÃo PEDRO SCAlZILli e Luis FeliPe SPINELli destacam os três primeiros elementos:

"podemos elencar quatro elementos que caracterizam a prática de insider trading. O primeiro deles é que a informacão utilizada deve ser relevante (...). É, portanto, em linhas gerais, toda e qualquer decisão do controlador, deliberação da assembléia-geral ou dos órgãos de administração da companhia aberta, ou qualquer outro fato de caráter político administrativo, técnico, negocial ou econômico-financeiro ocorrido ou relacionado aos seus negócios, que possa influir, de modo ponderável, na cotação dos seus valores mobiliários e na decisão dos investidores de comprar, vender ou manter esses títulos.

(...) Mas não basta que a informação seja relevante: é necessário que ela seja sigilosa também, caracterizando-se, como tal, pelo simples fato de ainda não ter 
sido divulgada ao mercado. Sendo relevante e sigilosa, é, consequentemente, uma informação privilegiada.

(...) O terceiro elemento é o uso dessa informacão privilegiada para a negociacão com as acões da companhia" 135.

Com relação ao quarto e último elemento, NELSON EIZIRIK et al:

"O tipo - uso de informação privilegiada - apresenta elemento subjetivo especial, tratando-se, portanto, de dolo específico: $o$ insider deve não só ter a consciência da ilicitude, como também desejar o resultado, a vantagem indevida ${ }^{136}$.

Desse modo, a ausência de apenas um desses requisitos já seria suficiente para descaracterizar a prática de insider trading.

Com a reforma da Lei das S.A., por meio da Lei $\mathrm{n}^{\circ} 10.303 / 2001$, a vedação de negociar com informação privilegiada passou a se estender a terceiros, e não mais apenas àqueles que estariam "por dentro" dos negócios da companhia e, portanto, teriam acesso direto às informações.

A nova redação do $\S 4^{\circ}$ do art. 155 passou a vedar " $a$ utilização de informação relevante ainda não divulgada, por qualquer pessoa que a ela tenha tido acesso, com a finalidade de auferir vantagem, para si ou para outrem, no mercado de valores mobiliários".

Com isso, a doutrina passou a classificar como insider primário aquele que obtivesse as informações privilegiadas diretamente da companhia, em função do exercício de algum cargo, função ou da condição de acionista controlador e de insider secundário aquele que tivesse acesso às informações por meio de algum insider primário ${ }^{137}$.

\footnotetext{
${ }^{135}$ SCALZILLI, João Pedro; SPINELLI, Luis Felipe. A Racionalidade Econômica do Combate ao Insider Trading: Assimetria de Informação e Dano ao Mercado, in: Revista de Direito Mercantil $\mathrm{n}$. 147, Julho-Setembro, 2007, pp. 44 e 45, grifou-se e destacou-se

${ }^{136}$ EIZIRIK, Nelson; GAAL, Ariádna B.; PARENTE, Flávia; HENRIQUES, Marcus de Freitas. Mercado de Capitais: Regime Jurídico. $3^{\mathrm{a}}$ ed. Renovar: Rio de Janeiro, 2011, p .564.

${ }^{137}$ EIZIRIK, Nelson; GAAL, Ariádna B.; PARENTE, Flávia; HENRIQUES, Marcus de Freitas. Mercado de Capitais: Regime Jurídico. $3^{\mathrm{a}}$ ed. Renovar: Rio de Janeiro, 2011, p .563.
} 
A norma que proíbe a prática de insider trading visa a tutelar, principalmente, a eficiência do mercado. Um mercado eficiente é aquele cujas cotações dos valores mobiliários refletem, em tempo real, as informações disponíveis a respeito das companhias. Nesse sentido, "quanto mais rápida for a reação dos títulos às novas informações, mais eficiente será o mercado" ${ }^{138}$.

Por sua vez, na tentativa de alcançar a eficiência do mercado, as normas legais e regulamentares estabeleceram o princípio do full and fair disclosure, mediante o qual as companhias abertas, por meio de seus diretores de relações com investidores, devem divulgar todas as informações disponíveis acerca de seus negócios.

O princípio do full and fair disclosure tem por objetivo garantir que todos os investidores possuam as mesmas informações ao mesmo tempo (simetria informacional), a fim de que todos possam negociar em posse das mesmas informações. Dessa forma, permitir que os insiders negociassem em posse de informação privilegiada não divulgada no mercado, com o intuito de obter vantagem para si ou para outrem, desequilibraria o mercado.

Ademais, coibir o insider tem por objetivo assegurar a confiabilidade no mercado. O insider possui uma vantagem informacional em comparação com os outros investidores, o que o colocaria um passo à frente destes que, por sua vez, estariam negociando sem o conhecimento de todas as informações relevantes acerca daquela companhia.

Assim, diante de um mercado estruturado para beneficiar apenas alguns poucos que têm acesso às informações confidenciais das companhias, os demais investidores acabariam por sentir-se inseguros em investir em um mercado que não estivesse corretamente precificado e, fatalmente, perderiam a credibilidade no mercado.

${ }^{138}$ EIZIRIK, Nelson. Questões de Direito Societário e Mercado de Capitais. $1^{\mathrm{a}}$ ed. Rio de Janeiro: Forense, 1987, p. 63. 
O Diretor Wladimir Castelo Branco, no âmbito do Processo Administrativo Sancionador CVM n 33/00, julgado em 20.12.2002 destaca a importância da coibição do insider trading:

"Desde logo, não é demais lembrar que a regulação do mercado visa a garantir aos investidores a disponibilidade ampla de informações confiáveis e que a base legal da regulação do insider trading, além do princípio da transparência, está apoiada na teoria da apropriação indevida de informações obtidas em razão do cargo ou função para benefício pessoal, da vantagem indevida que o insider possui frente à sua contraparte e do efeito adverso que o insider trading produz na estabilidade do mercado em termos de sua transparência e eficiência”.

\subsection{A Instrução CVM no 358 e a Presunção Relativa}

A Instrução CVM n 358 , de 03 de janeiro de 2002 ("Instrução CVM n 358”), buscou regulamentar, em seu art. 13, a proibição à prática de insider trading. Para tanto, estabeleceu vedações às negociações realizadas na pendência de divulgação de informações relevantes aos negócios da companhia.

O caput do art. 13 teve a função de regulamentar a proibição da conduta típica do insider primário, prevista no $\S 1^{\circ}$ do art. 155 da Lei das S.A. Confira-se a sua redação:

Art. 13. Antes da divulgação ao mercado de ato ou fato relevante ocorrido nos negócios da companhia, é vedada a negociação com valores mobiliários de sua emissão, ou a eles referenciados, pela própria companhia aberta, pelos acionistas controladores, diretos ou indiretos, diretores, membros do conselho de administração, do conselho fiscal e de quaisquer órgãos com funções técnicas ou consultivas, criados por disposição estatutária, ou por quem quer que, em virtude de seu cargo, função ou posição na companhia aberta, sua controladora, suas controladas ou coligadas, tenha conhecimento da informação relativa ao ato ou fato relevante.

Por sua vez, o $\S 1^{\circ}$ do art. 13 da Instrução CVM n 358 buscou regulamentar a vedação da conduta usual do insider secundário, prevista no $\S 4^{\circ}$ do art. 155 , da Lei das S.A.: 
Art. $13, \S 1^{\circ}$. A mesma vedação aplica-se a quem quer que tenha conhecimento de informação referente a ato ou fato relevante, sabendo que se trata de informacão ainda não divulgada ao mercado, em especial àqueles que tenham relação comercial, profissional ou de confiança com a companhia, tais como auditores independentes, analistas de valores mobiliários, consultores $e$ instituições integrantes do sistema de distribuição, aos quais compete verificar a respeito da divulgação da informação antes de negociar com valores mobiliários de emissão da companhia ou a eles referenciados.

A Instrução CVM n 358 exigiu, portanto, apenas a existência de informação relevante e o acesso privilegiado a essa informação em virtude de cargo ou função ocupada na companhia para vedar a negociação de valores mobiliários.

Com isso, a norma regulamentar acabou por criar uma presunção de que aquele que, em posse de informação privilegiada não divulgada no mercado, negociasse com valores mobiliários da companhia estaria fazendoo com a finalidade de auferir vantagem indevida, incidindo na prática de insider trading.

A criação da presunção regulamentar decorreu das evidentes dificuldades em se provar o elemento subjetivo da conduta do insider, qual seja, a utilização da informação privilegiada com a finalidade de obter vantagem.

MARCELO TRINDADE esclarece a questão da presunção regulamentar:

“A Instrução 358/2002 dispensou, portanto, ao regulamentar a vedação legal, dois requisitos exigidos pela Lei das $S / A$ : a 'utilização' dessa informação 'no mercado de valores mobiliários' e a 'finalidade de auferir vantagem, para si ou para outrem'. Assim agindo, a norma regulamentar não restringiu a lei regulamentada - o que a tornaria ilegal -, mas, na verdade, estabeleceu uma presunção: a de que qualquer negociação realizada por quem tenha acesso consciente, por meio da companhia, à informação relevante não divulgada é realizada com a finalidade de auferir a vantagem indevida vedada pela lei. Trata-se, contudo, como parece óbvio, de presuncão relativa (iuris tantum), que admite prova em contrário - até mesmo porque, insista-se, se assim não fosse a norma regulamentar teria 
extrapolado o mandato legal, ao tornar mais restrita a hipótese de incidência da norma regulamentada, e seria, por isso, ela própria ilegal. Em outras palavras, a presunção regulamentar serve para inverter o ônus da prova no que se refere aos elementos da conduta vedados na lei que estão ausentes na norma administrativa = quais sejam, a utilizacão da informacão e a finalidade de obter vantagem no mercado de valores mobiliários $" 139$.

Como bem observa o autor, a presunção estabelecida pela autarquia é relativa - pois, caso contrário, a norma regulamentar estaria extrapolando os limites legais - e admite, portanto, prova em contrário.

Caberá ao acusado provar que não tinha conhecimento da informação privilegiada quando negociou ou que não possuía a finalidade de auferir vantagem (demonstrando seguir um padrão de negociação, por exemplo). $\mathrm{O}$ que ocorre é uma inversão no ônus da prova.

Importante mencionar que a presunção iuris tantum só alcança o insider primário, cabendo à CVM a prova efetiva de que o insider secundário teve acesso à informação privilegiada e que negociou com a finalidade de auferir vantagem.

Justamente por tratar-se de presunção relativa a que recai sobre o insider primário é que a própria Instrução CVM no 358 estabeleceu duas situações em que ela não é aplicável: (i) quando a negociação decorre do exercício de opção de compra previsto em plano de outorga de opção previamente aprovado em assembleia; e (ii) quando a negociação ocorre em consonância com a política de negociação previamente aprovada.

As exceções expressamente previstas nos parágrafos $6^{\circ}$ e $7^{\circ}$ do art. 13 possuem elementos capazes de afastar a presunção relativa estabelecida pela norma. São hipóteses em que é possível, de antemão, assegurar que a decisão

\footnotetext{
139 TRINDADE, Marcelo Fernandez, Vedações à Negociação de Valores Mobiliários por Norma Regulamentar: Interpretação e Legalidade, in Temas de Direito Societário e Empresarial Contemporâneos, São Paulo: Malheiros, 2011, p. 458, destacou-se.
} 
de negociar do agente não foi motivada pela posse de informação relevante não divulgada ao mercado ${ }^{140}$.

Com isso, é possível concluir que o regulador não pretendeu proibir toda e qualquer negociação na pendência de divulgação de fato relevante, mas todas aquelas realizadas com o uso indevido de informação privilegiada $^{141}$.

Portanto, ainda que incida a presunção relativa nos casos de negociação, pelas pessoas indicadas no caput do art. 13, nos períodos vedados, caberá a possibilidade de produção de prova em contrário.

\subsection{Mútuo de Ações e a Vedação de Negociar}

Diante de todas essas observações, pode-se passar a analisar a questão central deste Capítulo, qual seja, a incidência da vedação de negociar no mútuo de ações.

Não restam dúvidas de que o mútuo de ações importa em uma negociação, uma vez que, por conta da própria natureza jurídica do contrato, acarreta transferência de propriedade do mutuante para o mutuário. Pode tratar-se, inclusive, de operação cursada em bolsa, por meio do sistema BTC.

Com efeito, incidem sobre o mútuo de ações as regras sobre a vedação de negociar estabelecidas na Instrução CVM no 358 e as presunções nela estabelecidas. Portanto, caberá analisar apenas se é possível afastar, a priori, as presunções regulamentares previstas no referido normativo na operação de mútuo de ações.

${ }^{140}$ Ibid., p. 462.

${ }^{141}$ Idem. 
Em recente trabalho sobre o tema ${ }^{142}$, MARCELO TRINDADE analisou cuidadosamente a situação do mutuante e do mutuário de forma individual. O mesmo será feito a seguir a fim de que sejam apontadas as principais diferenças em cada hipótese.

\subsubsection{A Situação do Mutuante}

Imagine-se uma situação em que um administrador ou acionista controlador (ou relevante) de companhia aberta deseje emprestar suas ações na pendência da divulgação de fato relevante.

Primeiramente, é importante destacar que apesar de a operação de mútuo de ações acarretar a transferência da propriedade das ações do mutuante para o mutuário, aquele se mantém economicamente exposto ao ativo.

Isto é, como bem aponta MARCELO TRINDADE, "ao final do contrato de mútuo o mutante receberá de volta as ações mutuadas - ou, mais propriamente, a mesma quantidade de ações mutuadas - e, portanto, necessariamente sofrerá a perda ou obterá o ganho que já sofreria ou obteria, caso não houvesse emprestado as acões" ${ }^{143}$.

Assim, se a cotação das ações cair no período compreendido entre a data do empréstimo e a do vencimento do contrato, o mutuante sofrerá a perda no momento em que recebê-las de volta; do mesmo modo, obterá ganhos se a cotação subir.

A transferência de propriedade, portanto, ocorre apenas no âmbito jurídico, de modo que os efeitos econômicos da detenção das ações serão, ao final, sofridos pelo mutuante. Como dito, no vencimento do contrato, o mutuante receberá a mesma quantidade de ações de mesma espécie das que

\footnotetext{
${ }^{142}$ TRINDADE, Marcelo Fernandez. Mútuo de Ações $e$ Insider Trading. In: CASTRO, Rodrigo R. Monteiro; WARDE JÚNIOR, Walfrido Jorge; GUERREIRO, Carolina Dias Tavares (coords.). Direito Empresarial e Outros Estudos em Homenagem ao Professor José Alexandre Tavares Guerreiro. São Paulo: Quartier Latin, 2013, p. 518 a 535.

${ }^{143}$ Ibid., p. 530, destacou-se.
} 
emprestou, juntamente com os ganhos ou perdas advindos da titularidade daquelas ações.

Confira-se a lição de GEERT T. M. J. RAAIJMAKERS:

"In securities lending shares are therefore lent not in a legal sense, but at the very most in an economic sense. If the lender "lends" a hundred shares in Royal Oil to a borrower, they remain economically for his account and risk. That means that he 'must hold them on his balance sheet'"']44.

O então Diretor da CVM Otavio Yazbek também observou tais circunstâncias quando do julgamento do Processo Administrativo CVM no SP2011/0304:

"O emprestador de ações não as aliena como se as tivesse vendido. Ele não recebe, em troca pelas ações que entrega à outra parte, o valor daquelas (o "principal", como se diz), mas sim o pagamento de uma taxa de juros. Tanto assim que, do ponto de vista econômico se costuma dizer que ele mantém a "exposição à companhia". (...) ele mantém aquela verdadeira exposição econômica, seja porque, ao emprestar suas ações, ele não está operando em mercado tendo em vista oscilações de preco - ele não aufere ganho daquelas oscilac̃ões e a sua conduta não é nem capaz de produzi-las de forma direta. O emprestador realiza uma operação de renda fixa, na verdade ${ }^{, 145}$.

Portanto, em regra, o mutuante não negocia com a finalidade de auferir vantagem com base em informação privilegiada por ele detida. As perdas ou ganhos decorrentes da detenção das ações serão, ao final, sofridas por ele como se, a todo tempo, fossem de sua propriedade.

Ocorre que, recentemente, a área técnica da CVM se manifestou por meio do OFÍCIO-CIRCULAR/CVM/SEP/N 01/2014 no sentido de que a

\footnotetext{
${ }^{144}$ Tradução livre: "No empréstimo de ações, as ações não são emprestadas no seu sentido jurídico, mas, no máximo, no seu sentido econômico. Se o mutuante empresta uma centena de ações de emissão da Royal Oil ao mutuário, elas permanecem economicamente por sua conta e risco. Isso significa que ele 'deve mantê-las em seu balanço"'. RAAIJMAKERS, Geert T. M. J. Securities Lending and Corporate Governance. Maastricht University Faculty of Law, Forthcoming, 2007, p. 1. Disponível em <http://papers.ssrn.com/sol3/papers.cfm?abstract_id=928312>. Acesso em 10/04/2014.

${ }^{145}$ Processo Administrativo CVM n ${ }^{\circ}$ SP2011/0304, Dir. Rel. Otavio Yazbek, j. em 16.02.2012.
} 
vedação de negociar contida no art. 13 da Instrução CVM no 358 se aplicaria também no caso de mútuo de ações, "inclusive nos casos em que a pessoa atua como doadora do empréstimo".

A justificativa da área técnica da autarquia teve por base dois argumentos: (i) a operação consiste, legalmente, em uma transferência de propriedade (mesmo que temporária); e (ii) o contrato de empréstimo permite ao doador optar pela incidência da taxa de remuneração sobre a cotação vigente na data de fechamento ou de vencimento do contrato.

O primeiro argumento pode ser de pronto rebatido. A transferência de propriedade no âmbito jurídico "não é capaz, economicamente, de evitar a perda futura, ou de permitir a obtenção de um ganho que já não seria obtido por força da propriedade prévia das ações" ${ }^{\prime 16}$. Dessa forma, o requisito da "finalidade de auferir vantagem indevida" com a operação, necessário para a caracterização do insider trading, poderia ser afastado a priori.

Já com relação ao segundo argumento, poder-se-ia imaginar uma situação em que o mutuante, na posse de informação privilegiada benéfica aos negócios da companhia, optasse pela incidência de taxa de remuneração, para pagamento do mútuo, sobre a cotação vigente na data de vencimento do contrato.

Assim, ciente de que a informação refletiria na cotação das ações, fazendo-as subir, o mutuante obteria uma melhor taxa ao optar pela incidência da cotação de vencimento, auferindo vantagens. No caso do contrato na modalidade callable, ele poderia, inclusive, antecipar o vencimento do contrato para se beneficiar do momento em que a cotação estivesse melhor refletindo a informação então divulgada.

${ }^{146}$ TRINDADE, Marcelo Fernandez. Mútuo de Ações $e$ Insider Trading. In: CASTRO, Rodrigo R. Monteiro; WARDE JÚNIOR, Walfrido Jorge; GUERREIRO, Carolina Dias Tavares (coords.). Direito Empresarial e Outros Estudos em Homenagem ao Professor José Alexandre Tavares Guerreiro. São Paulo: Quartier Latin, 2013, p. 530. 
Por outro lado, é importante mencionar que a taxa padrão estabelecida pela BM\&FBOVESPA incide sobre a cotação vigente na data de fechamento do contrato, mais especificamente, sobre a média da cotação na sessão de negociação imediatamente anterior ao registro da operação. Assim, caso o mutuante optasse por utilizar uma taxa de remuneração diferente da padrão, as hipóteses de vedação de negociar deveriam incidir sobre ele.

Lembre-se que os movimentos típicos do insider são (i) a aquisição de ações para posterior revenda, ciente de informação privilegiada que reflita positivamente na cotação das ações, auferindo, portanto, ganhos com a oscilação da cotação; ou (ii) venda antecipada das ações a fim de evitar posteriores perdas, tendo em vista o conhecimento de informação privilegiada prejudicial aos negócios da companhia ${ }^{147}$.

Nenhuma dessas hipóteses ocorre numa operação em que o proprietário dê em empréstimo suas ações. Ele se mantém economicamente exposto ao ativo, sofrendo perdas e obtendo ganhos, ao final do contrato.

Portanto, a única situação em que se poderia vislumbrar a ocorrência de insider trading seria por meio da determinação, pelo mutuante, de uma taxa mais benéfica, tendo em vista o conhecimento de fato relevante não divulgado favorável aos negócios da companhia.

Conclui-se, portanto, que desde que o mutuante administrador ou controlador de companhia aberta observe à taxa padrão estabelecida pela BM\&FBOVESPA (incidente sobre a cotação na data de fechamento do contrato), estará afastada, a priori, a presunção de que a negociação tem por finalidade auferir vantagem indevida.

\subsubsection{A Situação do Mutuário}

${ }^{147}$ Ibid., p. 531. 
A situação do mutuário administrador ou acionista controlador (ou relevante) de companhia aberta que toma ações em empréstimo é, de fato, bem diversa da situação do mutuante.

Isso porque, como bem observa MARCELO TRINDADE, na posse de informações privilegiadas que venham a refletir negativamente na cotação das ações, esses mutuários "poderão, em tese, tomar ações emprestadas, aliená-las antes da queda da cotação, e recomprá-las depois da queda, para pagar o mútuo"148.

Dessa forma, obteriam um ganho indevido sobre a diferença do valor da cotação no momento da venda e de seu valor no momento da recompra, tendo em vista o conhecimento de informação privilegiada que, quando divulgada, produziria uma queda na cotação.

Conclui-se, portanto, que na operação em que o mutuário toma ações em empréstimo, não é possível afastar a priori a presunção relativa de que a negociação na pendência de fato relevante não divulgado se daria com a finalidade de auferir vantagens indevidas, por meio da utilização de tal informação privilegiada.

Assim, no caso específico do mutuário, a presunção regulamentar, prevista no art. 13 da Instrução CVM no 358, incidirá em qualquer hipótese, de modo que será vedado às pessoas enumeradas no caput do dispositivo a realização de operações de mútuo de ações nestes períodos, caso figurem na ponta tomadora.

\subsubsection{A Implementação de Políticas de Negociação}

148 Ibid., p. 532. 
Nos termos do art. 15 da Instrução CVM n $358^{149}$, é facultada ${ }^{150}$ às companhias abertas a implementação de política de negociação que deverá ser aprovada por meio de deliberação do Conselho de Administração. Por meio dessas políticas, “as pessoas vinculadas são autorizadas a negociar em momentos futuros previamente determinados ou determináveis, e a prévia determinação, na Política, de tais situações, afastará a incidência das normas de vedação regulamentar à negociaç̃â" ${ }^{151}$.

Como visto, o $\S 7^{\circ}$ do art. 13 da mesma instrução estabelece que a vedação de negociar por administradores e acionistas controladores (ou relevantes) de companhia aberta, na pendência de fato relevante não divulgado no mercado, não se aplica aos casos de negociação em conformidade com política de negociação previamente aprovada.

Portanto, caso a operação de mútuo de ações seja realizada em consonância com política de negociação previamente aprovada - que deverá ser bem detalhada e precisa, ou até, como sugere MARCELO TRINDADE ${ }^{152}$, complementada por políticas individuais estabelecidas para os potenciais insiders - servirá como prova contrária à presunção regulamentar de utilização de informação privilegiada.

Isso porque, como visto, a intenção da norma é impedir que a negociação tenha por finalidade a obtenção de vantagem mediante a

\footnotetext{
${ }^{149}$ Instrução CVM nº 358, art. 15: “A companhia aberta poderá, por deliberação do conselho de administração, aprovar política de negociação das açães de sua emissão por ela própria, pelos acionistas controladores, diretos ou indiretos, diretores, membros do conselho de administração, do conselho fiscal e de quaisquer órgãos com funções técnicas ou consultivas, criados por disposição estatutária".

150 "A política de negociação de valores mobiliários, prevista no artigo 15 da Instrução CVM n 358/02, é de formulação facultativa. (...) Os emissores registrados na categoria A que possuírem essa política devem encaminhá-la pelo Sistema IPE”. OFÍCIO-CIRCULAR/CVM/SEP/Nº 01/2014, p. 64.

${ }^{151}$ TRINDADE, Marcelo Fernandez. Mútuo de Ações e Insider Trading. In: CASTRO, Rodrigo R. Monteiro; WARDE JÚNIOR, Walfrido Jorge; GUERREIRO, Carolina Dias Tavares (coords.). Direito Empresarial e Outros Estudos em Homenagem ao Professor José Alexandre Tavares Guerreiro. São Paulo: Quartier Latin, 2013, p. 532, destacou-se.

${ }^{152}$ Idem.
} 
utilização de informação privilegiada e não simplesmente impedir a mera negociação.

Dessa forma, a implementação e estrito cumprimento de tal política seria uma forma de comprovar que a decisão de negociar fora tomada antes - no momento da aprovação da política - e não no efetivo momento da negociação. Assim, ainda que tivesse conhecimento da informação privilegiada, a presunção ficaria afastada, pois o requisito subjetivo - a finalidade de auferir vantagem indevida com a negociação - não estaria presente ${ }^{153}$.

Ainda que, como visto, aos potenciais insiders que desejem atuar como mutuantes na operação de empréstimo de ações não incida a presunção regulamentar (desde que, é claro, obedeçam à taxa de remuneração padrão estabelecida pela BM\&FBOVESPA), seria recomendável a previsão dessas negociações nas políticas individuais e gerais de negociação das companhias abertas, inclusive, como um compromisso de transparência da companhia para com o mercado.

MARCELO TRINDADE explica:

“(...) não se deve excluir a utilidade da inclusão das negociacõos decorrentes de mútuo de aç̃es por insiders como operações previstas nas políticas geral e individual de negociação. E isso porque é preciso reconhecer que as operacões realizadas por insiders estão submetidas a um escrutínio especial, pelos investidores e pelas normas regulamentares emanadas da CVM e da BM\&FBOVESPA ${ }^{\prime \prime} 154$.

A relevância que a CVM e a BM\&FBOVESPA conferem ao tema pode ser traduzida por meio da norma contida no art. 11 da Instrução CVM $\mathrm{n}^{\circ} 358$, que exige a divulgação mensal de formulário contendo a titularidade

\footnotetext{
153 Ibid., p. 533.

154 TRINDADE, Marcelo Fernandez. Mútuo de Ações $e$ Insider Trading. In: CASTRO, Rodrigo R. Monteiro; WARDE JÚNIOR, Walfrido Jorge; GUERREIRO, Carolina Dias Tavares (coords.). Direito Empresarial e Outros Estudos em Homenagem ao Professor José Alexandre Tavares Guerreiro. São Paulo: Quartier Latin, 2013, p. 533, destacou-se.
} 
e as negociações realizadas com valores mobiliários de emissão da companhia por membros da administração, do conselho fiscal e de órgãos com funções técnicas ou consultivas e faculta tal divulgação aos acionistas controladores (todos estes potenciais insiders primários).

O objetivo da norma é garantir a transparência ao mercado, a fim de que seja possível, aos investidores, verificar o grau de alinhamento de interesse dos potenciais insiders com a companhia (se estão investindo ou desinvestindo na companhia). A norma também visa a auxiliar os reguladores a "verificar a possibilidade de manipulação de mercado pelos agentes com alto nível de informação e interesse nos resultados sociais, como são os insiders" $" 155$.

Por isso, a inclusão das operações de mútuo de ações nas políticas individuais e gerais de negociação das companhias teria por objetivo garantir ao mercado uma "adequada percepção (...) da intenção futura dos insiders quanto à negociação com as ações"156, além de ser capaz de assegurar um padrão quanto à realização dessas operações, afastando qualquer possível alegação de manipulação de mercado, "seja em termos de cotações, seja em termos de liquidez" ${ }^{\prime 157}$.

Por fim, como exposto, com relação às operações de mútuo de ações, a elaboração de políticas de negociação será capaz de afastar, nos casos em que não se pode fazê-lo a priori (quando o potencial insider atue como mutuário em qualquer caso ou como mutuante, mas não obedeça à taxa padrão do BTC), a vedação de negociar, visto que o elemento subjetivo - a finalidade de auferir vantagem indevida com a operação - não estará presente.

\footnotetext{
155 Ibid., p. 534.

156 Idem.

157 TRINDADE, Marcelo Fernandez. Mútuo de Ações e Insider Trading. In: CASTRO, Rodrigo R. Monteiro; WARDE JÚNIOR, Walfrido Jorge; GUERREIRO, Carolina Dias Tavares (coords.). Direito Empresarial e Outros Estudos em Homenagem ao Professor José Alexandre Tavares Guerreiro. São Paulo: Quartier Latin, 2013, p. 534.
} 


\section{Conclusão}

As operações de mútuo de ações realizadas na bolsa, via sistema BTC, possuem grande importância no mercado, principalmente, na redução do risco de liquidação, visto que os "tomadores" têm a possibilidade de tomar ações em empréstimo a fim de cobrir posições short e no aumento de liquidez dos ativos, uma vez que, em regra, são destinadas à negociação.

Desde 2006, essas operações vêm experimentando um notável crescimento. Em paralelo, começaram a surgir algumas questões a elas referentes que ainda não haviam sido objeto de aprofundado estudo.

O presente trabalho buscou trazer à tona algumas dessas questões, com o intuito de tentar esclarecê-las.

Como o objetivo da operação é a transferência da propriedade das ações do "doador" para o "tomador" a fim de que este possa usar e dispor delas, mediante o pagamento de juros, obrigando-se a entregar, ao final do contrato, ações equivalentes (uma vez que se trata de bens fungíveis, como demonstrado) foi possível definir sua natureza jurídica como um contrato de mútuo feneratício.

Rejeitadas quaisquer outras hipóteses de definição da natureza jurídica da operação, constatou-se o equívoco na nomenclatura utilizada pelo mercado. Chamam de aluguel o que na verdade é mútuo.

Tendo em vista tratar-se de mútuo, foram analisados os principais efeitos que a transferência da propriedade poderia gerar em alguns dos direitos políticos e patrimoniais conferidos aos acionistas.

O direito de participar nos lucros, como o direito patrimonial de maior importância, haja vista sua ligação com a atividade fim das companhias (o escopo do lucro), pode ser efetivamente exercido pelos acionistas por meio da distribuição de dividendos. 
Como exposto, terão direito ao recebimento de dividendos os acionistas que forem titulares ou usufrutuários das ações na data da declaração dos dividendos em assembleia geral.

Como o mútuo de ações acarreta a transferência da propriedade das ações, em regra, esse direito é também transferido. No entanto, por força das normas estabelecidas pelo BTC, o direito ao recebimento dos dividendos é garantido ao mutuante, de modo que será provisionado um crédito na sua conta para o pagamento dos proventos. É, portanto, um direito passível de cessão.

O direito de opção para subscrição de ações é também um direito patrimonial e tem por objetivo evitar a diluição da participação dos acionistas em uma companhia e, logicamente, garantir a manutenção de sua participação proporcional em decorrência de aumentos de capital. Como visto, só é passível de cessão após a deliberação de aumento de capital (antes disso, há apenas mera expectativa, direito abstrato), motivo pelo qual, antes de tal evento, poderá apenas ser objeto de promessa de cessão.

No mútuo de ações, tal direito é também transferido juntamente com a propriedade das ações, de modo que, será assegurado ao mutuário, caso detenha as ações durante o período indicado pela companhia para seu exercício. Ocorre que, também por força das normas do BTC, poderá ser objeto de promessa de cessão ao mutuante, caso o mutuário assim concorde.

Caso contrário, será permitido ao mutuante que "exerça o direito de preferência legal via sistema BTC". Isto é, caso manifeste seu interesse dentro do cronograma estabelecido pela companhia, será debitado de sua conta o valor referente ao pagamento da subscrição e creditado na conta do mutuário para que este vá ao mercado adquirir as novas ações. A diferença entre o preço de mercado das ações e o preço de subscrição das ações estabelecido pela companhia será arcada inteiramente pelo mutuário. 
O BTC buscou, portanto, estabelecer mecanismos com o objetivo de manter a operação de empréstimo de ações atraente para o mutuante, de modo que lhe fosse assegurado o exercício dos direitos de recebimento de dividendos e de subscrição de ações pelas condições estabelecidas pela companhia emissora.

O direito de recesso, por sua vez, é direito excepcional e taxativo visto que acaba por sobrepor interesses individuais ao interesse social - que tem por objetivo permitir aos acionistas dissidentes retirar-se da companhia, mediante o reembolso do valor de suas ações, nas hipóteses previstas em lei.

Apesar de ser direito essencial do acionista, seu exercício impõe um ônus excessivo à companhia - que é obrigada a pagar o valor do reembolso das ações -, motivo pelo qual a Lei das S.A. estabeleceu alguns requisitos para o seu exercício.

O proprietário do direito de recesso, como se demonstrou, é aquele que detém a titularidade ininterrupta das ações desde a data de publicação da convocação da assembleia ou da divulgação de fato relevante objeto da operação até a data de seu efetivo exercício.

A Lei ${ }^{\circ} 9.457$ antecipou a data limite da realização da assembleia para a publicação de sua convocação ou de divulgação do fato relevante justamente com o fim de eliminar a chamada "indústria do recesso".

Dessa forma, ao transferir a titularidade das ações ao mutuário, o mutuante perde a possibilidade de exercer o direito de recesso. Por sua vez, o mutuário só terá legitimidade para exercê-lo, caso detenha as ações ininterruptamente entre a data de publicação da convocação da assembleia ou da divulgação de fato relevante objeto da operação e a data de seu efetivo exercício. 
Nas operações contratadas no curso deste período, tanto mutuante quanto mutuário perdem a possibilidade do exercício do direito, uma vez que lhes falta o requisito da titularidade ininterrupta.

Como se expôs, tais constatações não prejudicam ou comprometem a operação de mútuo de ações, uma vez que um mercado ativo de empréstimo demonstra, em regra, significativo grau de liquidez, já que os mutuários precisam contar com a liquidez para poder recomprar os títulos e entregá-los ao mutuante. E, possuindo liquidez, não há sequer direito de recesso em determinadas hipóteses, caso se verifique também a observância do critério de dispersão.

O direito de voto, por sua vez, representa um direito político conferido aos acionistas por meio do qual participam para a formação de vontade da sociedade. A Lei das S.A. determina que deverá ser exercido no interesse social, entendido como o interesse dos acionistas considerados coletivamente (e na condição de acionistas).

Caso o voto seja proferido com o fim de causar dano à companhia ou a outros acionistas, ou de obter, para si ou para outrem, vantagem a que não faz jus e de que resulte, ou possa resultar, prejuízo para a companhia ou para outros acionistas, será considerado abusivo.

Assim, o acionista deverá responder pelos danos causados pelo exercício abusivo do direito de voto e, caso seu voto tenha prevalecido, será passível de anulação.

Especificamente, no mútuo de ações, o direito de voto é transferido ao mutuário, devendo ser por ele exercido desde que detenha as ações na data de realização da assembleia. Como exposto, o direito de voto é personalíssimo, sendo vedada sua cessão a terceiros.

A questão do exercício do voto pelo mutuário é, de certa forma, polêmica, uma vez que há uma dissociação entre o interesse econômico na 
companhia e o próprio direito de voto. O tomador mantém-se na qualidade de acionista por prazo determinado e não paga o preço das ações, não realizando um investimento na sociedade.

Com isso, foi destacada a preocupação a respeito da possibilidade de o mutuário exercer o direito de voto, inclusive, no interesse contrário ao da companhia, tendo em vista a falta de interesse econômico que nela possui.

Como visto, tal situação pode ser solucionada por duas vias: (i) uma repressiva: as sanções aplicáveis em caso de voto abusivo incidirão sobre o mutuário, uma vez que exercerá o voto na qualidade de acionista da companhia; e (ii) outra preventiva: a BM\&FBOVESPA estabelece limites de concentração por investidor tomador para realizar operações de mútuo de ações.

Por fim, foi analisada nesse trabalho a incidência das vedações de negociar, previstas na Instrução CVM no 358, no mútuo de ações. Como se expôs, para a caracterização da prática de insider trading, é necessária a presença de quatro requisitos: (i) existência de uma informação relevante ainda não divulgada ao mercado; (ii) acesso privilegiado do agente a essa informação; (iii) efetiva utilização da informação em negociação no mercado de valores mobiliários; e (iv) finalidade do agente de, ao utilizar a informação, auferir vantagem para si ou para outrem.

Diante da dificuldade de comprovação do elemento subjetivo, isto é, da finalidade de utilizar a informação privilegiada para auferir vantagem, a CVM criou uma presunção relativa de que administradores e acionistas controladores (ou relevantes) que negociassem na pendência de divulgação de fatos relevantes, possuiriam conhecimento da informação privilegiada e estariam negociando a fim de utilizá-la para obter vantagens.

No entanto, por se tratar de presunção relativa, admite prova em contrário. Trata-se apenas de situações em que há inversão do ônus da prova. Nesse sentido, a própria instrução estabeleceu hipóteses em que a vedação é 
afastada, tais como a negociação em conformidade com política de negociação previamente aprovada.

Para verificar a incidência dos períodos de vedação de negociar no mútuo de ações, foram analisadas as situações do mutuante e mutuário separadamente.

Com relação ao mutuante, concluiu-se que a presunção relativa de que a negociação é realizada com a finalidade de utilizar a informação privilegiada para auferir vantagem pode ser afastada a priori, desde que utilizada a taxa padrão estabelecida pela BM\&FBOVESPA.

Isso porque o mutuante se mantém economicamente exposto à variação da cotação das ações, uma vez que, ao final do contrato, ações equivalentes lhe serão entregues e ele, necessariamente, sofrerá as perdas e obterá os ganhos decorrentes da variação.

Caso opte por utilizar a taxa de remuneração incidente sobre a cotação do vencimento do contrato, e não a de fechamento, conforme padrão estabelecido pela BM\&FBOVESPA, o mutuante poderá, em posse de informação privilegiada favorável aos negócios da companhia, obter uma taxa mais favorável, auferindo ganhos indevidos. Nesse caso, verificou-se que a presunção regulamentar não pode ser de antemão afastada.

Com relação ao mutuário, em nenhuma hipótese é possível afastar a presunção a priori. Isso porque ele poderá, em posse de informação privilegiada que afete negativamente a cotação das ações, tomar ações emprestadas, aliená-las antes da queda da cotação, e recomprá-las depois da queda, para pagar o mútuo.

Com isso, auferirá vantagem indevida decorrente da variação da cotação que pôde antever, tendo em vista o conhecimento de informação privilegiada. 
Uma solução para afastar a presunção relativa em qualquer caso é a elaboração de políticas de negociação gerais e individuais, uma vez que, tendo sido determinada a decisão de negociar em momento anterior - o da aprovação das políticas - o requisito subjetivo não estará presente.

A importância de implementações de políticas de negociação está atrelada à possibilidade de se criar padrões de negociação dos potenciais insiders da companhia que serão adequadamente percebidos e recebidos pelo mercado.

Por fim, constatou-se que a previsibilidade das operações de mútuo de ações, poderá afastar possíveis alegações de que tais negociações possam ter sido realizadas com o objetivo de manipular as cotações ou a liquidez das ações de emissão da companhia em períodos importantes da vida social. 


\section{Bibliografia}

\section{Doutrina}

ASCARELLI, Tullio. O Problema das Sociedades Anônimas e Direito Comparado. São Paulo: Saraiva \& Cia, 1945.

BARBOSA, Marcelo. Direitos dos Acionistas. In: LAMY FILHO, Alfredo; PEDREIRA, José Luiz Bulhões (Coords.). Direito das Companhias. Vol. I. Rio de Janeiro: Forense, 2009.

BELOCH, Henrique Vargas. CVM Trata do Empréstimo de Ações em Nova Instrução.

<http://www.bmalaw.com.br/nova_internet/arquivos/BMA_Review/Newsle tter_BMA_Review_setembro_outubro_2006_pt.pdf>. Acesso em 03/03/2014.

BM\&FBOVESPA, Folheto BTC, mar 2010. http://www.bmfbovespa.com.br/pt-br/Servicos/download/Folheto-BTC.pdf. Acesso em 10 fev. 2014.

BORBA, José Edwaldo Tavares. Direito Societário. $6^{\mathrm{a}}$ ed. Rio de Janeiro: Renovar, 2001.

CAMPOS, Luiz Antônio de Sampaio. Utilização do Lucro do Exercício: Dividendo e Recompra. In: ADAMEK, Marcelo Vieira Von (Coord.). Temas de Direito Societário e Empresarial Contemporâneos. São Paulo: Malheiros, 2011 .

CAMPOS, Luiz Antonio de Sampaio. Notas sobre o Direito de Recesso e a Exigência de Titularidade Ininterrupta (Art. 137, $\S 1^{\circ}$ ). In: CASTRO, Rodrigo R. Monteiro de; WARDE JR., Walfrido Jorge; GUERREIRO, Carolina Dias Tavares (Coords.). Direito Empresarial e Outros Estudos de Direito em Homenagem ao Professor José Alexandre Tavares Guerreiro. São Paulo: Quartier Latin, 2013. 
CARVALHOSA, Modesto. Comentários à Lei de Sociedades Anônimas. Vol. I. 6 ${ }^{\text {a }}$ ed. São Paulo: Saraiva, 2011.

CARVAlHOSA, Modesto. Comentários à Lei de Sociedades Anônimas. Vol. II. 5ª ed. São Paulo: Saraiva, 2011.

COMPARATO, Fábio Konder. Novos Ensaios e Pareceres de Direito Empresarial. Rio de Janeiro: Forense, 1981.

COMPARATO, Fábio Konder. Valor de Reembolso no Recesso Acionário. In: Revista dos Tribunais. São Paulo: Revista dos Tribunais, v. 563, setembro, ano 71, 1982.

COMPARATO, Fábio Konder. Direito Empresarial: Estudos e Pareceres. São Paulo: Saraiva, 1995.

CUNHA, Rodrigo Ferraz Pimenta da. O Exercício de Voto na Sociedade Anônima. In: CASTRO, Rodrigo R. Monteiro de; ARAGÃO, Leandro Santos de (Coords.). Direito Societário: Desafios Atuais. São Paulo: Quartier Latin, 2009.

CUNHA, Rodrigo Ferraz Pimenta da. Estrutura de Interesses nas Sociedades Anônimas: Hierarquias e Conflitos. São Paulo: Quartier Latin, 2007.

EIZIRIK, Nelson. A Lei das S.A. Comentada. Vol. I. São Paulo: Quartier Latin, 2011.

EIZIRIK, Nelson. A Lei das S.A. Comentada. Vol. II. São Paulo: Quartier Latin, 2011.

EIZIRIK, Nelson. A Lei das S.A. Comentada. Vol. III. São Paulo: Quartier Latin, 2011.

EIZIRIK, Nelson; GAAL, Ariádna B.; PARENTE, Flávia; HENRIQUES, Marcus de Freitas. Mercado de Capitais: Regime Jurídico. $3^{\mathrm{a}}$ ed. Renovar: Rio de Janeiro, 2011. 
EIZIRIK, Nelson. Questões de Direito Societário e Mercado de Capitais. $1^{\mathrm{a}}$ ed. Rio de Janeiro: Forense, 1987.

FRANÇA, Erasmo Valladão Azevedo e Novaes. Conflito de Interesses nas Assembléias de S.A. São Paulo: Malheiros, 1993.

FRANÇA, Erasmo Valladão Azevedo e Novaes. Invalidade das Deliberações de Assembléia das S.A. São Paulo: Malheiros, 1999.

GOMES, Orlando. Introdução ao Direito Civil. $6^{\mathrm{a}}$ ed. Rio de Janeiro: Forense, 1979.

GOMES, Orlando. Contratos. 26 $6^{\mathrm{a}}$ ed. Rio de Janeiro: Forense, 2009.

HU, Henry T. C.; BLACK, Bernard. The Vote Buying: Empty Voting and Hidden (Morphable) Ownership. In: Southern California Law Review, Vol. 79, 2006. Disponível em $<$ http://papers.ssrn.com/sol3/papers.cfm?abstract_id=904004>. Acesso em 01/04/2014.

KALANSKY, Daniel; PEYSER, Luis. Empréstimo de Ações e o Mercado de Capitais. In: JUNIOR, Ecio Perin; KALANSKY Daniel; PEYSER, Luis (coord.). Direito Empresarial: Aspectos atuais de Direito Empresarial brasileiro e comparado. São Paulo: Método, 2005.

LAMY FILHO, Alfredo; PEDREIRA, José Luiz Bulhões. A Lei das S.A.: Pressupostos, Elaboração, Aplicação. Vol I. $3^{\mathrm{a}}$ ed. Rio de Janeiro: Renovar, 1997.

LAMY FILHO, Alfredo; PEDREIRA, José Luiz Bulhões. A Lei das S.A. Vol. II. $2^{\text {a }}$ ed. Rio de Janeiro: Renovar, 1996.

LEÃES, Luiz Gastão Paes de Barros. Estudos e Pareceres sobre Sociedades Anônimas. São Paulo: Revista dos Tribunais, 1989.

LEUTEWILER, Gabriel; COMIRAN, Giovana Cunha; HAENSEL, Taimi. Aluguel de Ações: Panorama do negócio jurídico, problemas do direito 
estrangeiro e a eficiência do modelo brasileiro e a questão do voto no direito brasileiro. In: Revista de Direito Mercantil, Industrial, Econômico e Financeiro. São Paulo: Malheiros, n. 161/162, jan/ago, 2012.

LOPES, Miguel Maria de Serpa. Curso de Direito Civil. Vol. IV. $4^{\text {a }}$ ed. Rio de Janeiro: Freitas Bastos, 1993.

MARTINS, Fran. Comentários à Lei das Sociedades Anônimas. 4ª ed. Rio de Janeiro: Forense, 2010.

MIRANDA, Pontes de. Tratado de Direito Privado: Parte Geral. Tomo II. $3^{a}$ ed. Rio de Janeiro: Borsoi, 1970.

MIRANDA, Pontes de. Tratado de Direito Privado: Parte Especial. Tomo XLII. $3^{\text {a }}$ ed. Rio de Janeiro: Borsoi, 1972.

MIRANDA, Pontes de. Tratado de Direito Privado: Parte Especial. Tomo L. $3^{\text {a }}$ ed. Rio de Janeiro: Borsoi, 1972.

MORAES, Maria Celina Bodin de. O procedimento de qualificação dos contratos e a dupla configuração do contrato de mútuo no direito civil brasileiro. Revista Forense, n. 309. Rio de Janeiro, 1990.

MUSSNICH, Francisco A. Maciel. Reflexões sobre o Direito de Recesso na Lei das Sociedades por Ações. In: LOBO, Jorge (coord.). Reforma da Lei das Sociedades Anônimas: Inovações e Questões Controvertidas da Lei $n^{o}$ 10.303, de 31.10.2001. $2^{\mathrm{a}}$ ed. Rio de Janeiro: Forense, 2002

PEDREIRA, José Luiz Bulhões; LAMY FILHO, Alfredo. Natureza $e$ Normas Gerais. In: LAMY FILHO, Alfredo; PEDREIRA, José Luiz Bulhões (coords.). Direito das Companhias. Vol. I. Rio de Janeiro: Forense, 2009.

PEDREIRA, Luis Eduardo Bulhões. Direito de Retirada. In: LAMY FILHO, Alfredo; PEDREIRA, José Luiz Bulhões (Coords.). Direito das Companhias. Vol. I. Rio de Janeiro: Forense, 2009. 
PEREIRA, Caio Mário da Silva. Instituições de Direito Civil: Contratos. Vol. III. $12^{\mathrm{a}}$ ed. Rio de Janeiro: Forense, 2006.

RAAIJMAKERS, Geert T. M. J. Securities Lending and Corporate Governance. Maastricht University Faculty of Law, Forthcoming, 2007. Disponível em <http://papers.ssrn.com/sol3/papers.cfm?abstract_id=928312>. Acesso em $10 / 04 / 2014$

REGO, Marcelo Lamy. Direitos dos Acionistas. In: LAMY FILHO, Alfredo; PEDREIRA, José Luiz Bulhões (Coords.). Direito das Companhias. Vol. I. Rio de Janeiro: Forense, 2009.

REQUIÃO, Rubens. Curso de Direito Comercial. Vol. II. 24a ed. São Paulo: Saraiva, 2005.

ROSMAN, Luiz Alberto Colonna. Modificação do Capital Social. In: LAMY FILHO, Alfredo; PEDREIRA, José Luiz Bulhões. Direito das Companhias. Vol. II. Rio de Janeiro: Forense, 2009.

SCALZILLI, João Pedro; SPINELLI, Luis Felipe. A Racionalidade Econômica do Combate ao Insider Trading: Assimetria de Informação e Dano ao Mercado, in: Revista de Direito Mercantil n. 147, Julho-Setembro, 2007.

SCHAHIN, Fernanda Kehdi. Vendas a Descoberto no âmbito do Empréstimo de Ações: estudo do modelo regulatório brasileiro. In: Revista de Direito Bancário e do Mercado de Capitais. São Paulo: Malheiros, n. 49, ano 13, jul/set, 2010.

TEIXEIRA Egberto Lacerda; GUERREIRO, José Alexandre Tavares. Das Sociedades Anônimas no Direito Brasileiro. Vol. I. São Paulo: José Bushatsky, 1979. 
TRINDADE, Marcelo Fernandez. Vedações à Negociação de Valores Mobiliários por Norma Regulamentar: Interpretação e Legalidade, in Temas de Direito Societário e Empresarial Contemporâneos, São Paulo: Malheiros, 2011.

TRINDADE, Marcelo Fernandez. Mútuo de Ações e Insider Trading. In: CASTRO, Rodrigo R. Monteiro; WARDE JÚNIOR, Walfrido Jorge; GUERREIRO, Carolina Dias Tavares (coords.). Direito Empresarial e Outros Estudos em Homenagem ao Professor José Alexandre Tavares Guerreiro. São Paulo: Quartier Latin, 2013.

VALVERDE, Trajano de Miranda. Sociedades por Ações (Comentários ao Decreto-Lei $n^{\circ} 2.627$ de 26 de setembro de 1940). Vol. II. $2^{\text {a }}$ ed. Rio de Janeiro: Forense, 1953.

WARDE JR. Walfrido Jorge. O direito é do proprietário. < http://www.capitalaberto.com.br/temas/legislacao-e-regulamentacao/odireito-e-do-proprietario/>. Acesso em 20/03/2014.

\section{Jurisprudência}

Processo Administrativo CVM nº SP2011/0304, Dir. Rel. Otavio Yazbek, j. em 16.02.2012.

Processo Administrativo CVM nº RJ2012/0249, Dir. Rel. Luciana Dias, j. em 16.02.2012.

Processo Administrativo CVM nº RJ2006/7840, j. em 06.11.2006 nos termos do MEMO/CVM/SEP/GEA-4/n. 102/06.

Processo Administrativo Sancionador CVM n ${ }^{\circ}$ 33/00, Dir. Rel. Wladimir Castelo Branco, j. em 20.12.2002.

\section{Regulamentação}

Instrução CVM no 249, de 11 de abril de 1996. 
Instrução CVM nº 358, de 3 de janeiro de 2002.

Instrução CVM n 441, de 10 de novembro de 2006.

Instrução CVM nº 480, de 7 de dezembro de 2009.

Instrução CVM nº 481, de 17 de dezembro de 2009.

Resolução CMN no 2.268, de 10 de abril de 1996.

Resolução CMN n 3.539, de 28 de fevereiro de 2008.

\section{Sites}

http://www.bmfbovespa.com.br/BancoTitulosBTC/Estatisticas.aspx?Idioma =pt-br. Acesso em 25 mar. 2014.

http://www.bmfbovespa.com.br/pt-br/Servicos/download/Folheto-BTC.pdf. Acesso em 10 fev. 2014.

http://www.group30.org/about.shtml. Acesso em 05 mar. 2014. 